\title{
Sulak Alanlarda Uzaktan Algılama ile Belirlenen Zamansal Değişime Kuraklığın Etkisinin İncelenmesi: Umurbey Deltası (Çanakkale) Örneği
}

\author{
Derya Çakaroz $^{*}$, Emre Özelkan ${ }^{2,3}$, Muhittin Karaman $^{4}$ \\ $1^{1 *}$ Çanakkale Onsekiz Mart Üniversitesi, Fen Edebiyat Fakültesi, Coğrafya Bölümü, Çanakkale, Türkiye (ORCID: 0000-0001-6723-3632), derya.cakaroz@gmail.com \\ ${ }^{2}$ Çanakkale Onsekiz Mart Üniversitesi, Mimarlık ve Tasarım Fakültesi, Şehir ve Bölge Planlama Bölümü, Çanakkale, Türkiye (ORCID: 0000-0002-2031-1610), \\ emreozelkan@comu.edu.tr \\ ${ }^{3}$ Çanakkale Onsekiz Mart Üniversitesi, Lisansüstü Eğitim Enstitüsü, Doğal Afetlerin Risk Yönetimi Anabilim, Çanakkale, Türkiye (ORCID: 0000-0002-2031-1610), \\ emreozelkan@comu.edu.tr \\ 4 İstanbul Teknik Üniversitesi, Maden Fakültesi, Jeoloji Mühendisliği Bölümü, İstanbul, Türkiye (ORCID: 0000-0002-8971-010X), mkaraman@itu.edu.tr
}

(İlk Geliş Tarihi 25 Eylül 2020 ve Kabul Tarihi 31 Aralık 2020)

(DOI: 10.31590/ejosat.799717)

ATIF/REFERENCE: Çakaroz, D., Özelkan, E. \& Karaman, M. (2020). Sulak Alanlarda Uzaktan Algılama ile Belirlenen Zamansal Değişime Kuraklığın Etkisinin İncelenmesi: Umurbey Deltası (Çanakkale) Örneği. Avrupa Bilim ve Teknoloji Dergisi, (20), 898-916.

\section{$\ddot{O} \mathbf{z}$}

Sulak alanlar dünya ekosisteminin dengesini ve devamlılığını sağlayan yeryüzünün en önemli ve kıymetli parçalarından biridir. Büyük bir sistemin parçaları olan bu alanlar, yer aldıkları sahanın iklimi, su kaynakları ve jeomorfolojik özelikleri gibi çevresel faktörlere karşı çok duyarlı olmakla birlikte, özellikle kuraklık sorunu ile karşı karşıyadır. Son zamanlarda uzaktan algılama ile sulak alanların izlenmesi, bu alanlara etki eden faktörlerin ve önem derecelerinin belirlenmesi ve sorunların çözümüne yönelik koruma ve geliştirme çalışmaları ağırlık kazanmıştır. Bu çalışmada 2013 ve 2019 yılları arasında yağışlı ve kurak dönem sonlarında Çanakkale ili sınırları içerisinde yer alan Umurbey Deltası'nda yer alan lagünlerdeki su varlığı uzaktan algılama yöntemleri ile belirlenmiş, su ile kaplı alanların alansal değişimlerine meteorolojik ve hidrolojik kuraklığın etkisi incelenmiştir. Çok zamanlı alansal değişimin belirlenmesinde 15 m mekansal çözünürlüklü Landsat-8 OLI (Operational Land Imager) multispektral pankeskinleştirilmiş uydu görüntülerinden üretilen Modifiye Edilmiş Normalize Fark Su İndisi (MNDWI), meteorolojik kuraklığın belirlenmesinde Standart Yağı̧̧ İndisi (SPI) ve hidrolojik kuraklık için ise evapotranspirasyon ve su bütçesi hesabını içeren Thornthwaite İklim Sınıflama metodu kullanılmıştır. Meteorolojik ve hidrolojik kuraklığın lagün alanına etkileri yağışlı ve kurak dönem sonlarına kadar olacak şekilde aylık ve mevsimlik ( 1 ve 3 aylık) dönemlerde incelenmiştir. Elde edilen sonuçlar lagün alanlarındaki değişimde meteorolojik kuraklık kısa inceleme dönemlerinde yağışı dönemin sonunda daha fazla etkili olmaktadır. Diğer taraftan hidrolojik kuraklığın ise (buharlaşma ve bitki ile su tüketiminin) kurak dönemi içeren tüm inceleme dönemlerinde alansal değişimde daha etkili olduğunu göstermektedir.

Anahtar Kelimeler: Sulak Alan, Uzaktan Algılama, MNDWI, Standart Yağış İndisi, Thornthwaite, Kuraklık.

\section{Investigation of the Effect of Drought on Temporal Change in Wetlands Determined by Remote Sensing: The Case Study in Umurbey Delta (Çanakkale)}

\begin{abstract}
Wetlands are one of the most important and precious parts of the Earth that provide the balance and continuity of the world ecosystem. These areas, which are parts of a large system, are very sensitive to environmental factors such as the climate of their site,
\end{abstract}

\footnotetext{
* Sorumlu Yazar: Çanakkale Onsekiz Mart Üniversitesi, Fen Edebiyat Fakültesi, Coğrafya Bölümü, Çanakkale, Türkiye, ORCID: 0000-0001-67233632,derya.cakaroz@gmail.com
} 
water resources and geomorphological features, but they are especially faced with the drought problem. Recently, monitoring of wetlands with remote sensing, determining the factors affecting these areas and their importance, and conservation and development studies for the solution of problems have gained importance. In this study, was determined remote sensing the presence of water in lagoons in the Umurbey Delta, which is located in the borders of Çanakkale province, the effect of meteorological and hydrological drought on the changes of water-covered areas were investigated between 2013 and 2019 at the end of rainy and dry periods. Modified Normalized Difference Water Index (MNDWI) produced from $15 \mathrm{~m}$ spatial resolution Landsat-8 OLI (Operational Land Imager) multispectral pansharpening satellite images in the determination of multi-temporal spatial change, Standard Precipitation Index (SPI) for meteorological drought and for hydrological drought Thornthwaite Climate Classification method, which includes the calculation of evapotranspiration and water budget, were used. The effects of meteorological and hydrological drought on the lagoon area were examined in monthly and seasonal (1 and 3 months) periods at the end of rainy and dry periods. The results showed that the meteorological drought is more effective in the short review periods at the end of the rainy season. On the other hand, the hydrological drought under the effect of evaporation and plant water consumption (i.e. evapotranspiration) is more effective in water area changes at the end of the dry season.

Keywords: Wetland, Remote Sensing, MNDWI, Standardized Precipitation Index, Thornthwaite, Drought.

\section{Giriş}

Deltalar, biyolojik çeşitlilik bakımından en zengin ekosistemlerden birini oluşturan sulak alanları barındırmaları sebebiyle önem taşımaktadır [1-3]. Biyolojik çeşitliliği, çevresel ve ekolojik dengenin devamlılığını sağlayan sulak alanlar karasal ve sucul ekosistemler arasında enerji akışı sağlayan, doğal ve beşerî girdi-çıktıları olan üretim sistemleridir [4-6].

Sulak alan ekosistemlerinin karmaşık yapısı yeraltı sularının beslenmesi, sel ve taşkın kontrol ve mikro iklim stabilizasyonu gibi ekolojik fonksiyonlar ve orman kaynakları, balıkçılık ve yem kaynakları gibi sosyo-ekonomik hizmetler ve ürünler sunmaktadır [7].

Sulak alanların özellikleri bulundukları bölgenin iklim, jeomorfoloji ve su kaynağı gibi çevresel etmenlerin etkisindedir [4]. Sulak alana su girdisi; doğrudan kar ve yağmur suyu, gel-git suları, yeraltı suyu, çevre alanlardan yüzey akışı ile gelen sular ile sağlanmaktadır [8]. Su çıkışları ise buharlaşma, terleme, yeraltına sızma, gel-git ile nehir ve derelerin kolları tarafindan dışarı drene edilmesi sonucunda meydana gelmektedir [4, 2]. Sulak alanlardan aşırı miktarda su tüketimi, sulak alanların bulunduğu havzalarda yeraltı sularının aşırı kullanımı, sistemi besleyen akarsular üzerindeki baraj vb. yapılarla suların tutulması, akarsuların yönlerinin değiştirilmesi gibi olaylar sulak alanlardaki hidrolojik dengeyi etkilemekte, bu alanların ve bu alanlara bağlı ekosistemin yok olmasına varan sonuçları doğurmaktadır. $[9,10]$.

Kıyı kesimlerde yer alan sulak alanlarda doğal hidrolojik süreçler, su seviyesi değişimi, dalga hareketleri ve gel-git etkisine bağlı olarak günlük ve aylık olarak değişim göstermektedir. Mevsimsel su değişimleri, yıl içindeki kurak ve yağışlı dönemlere paralel bir değişim gösterirken, uzun dönemli seviye değişimleri iklimsel değişimlere paralel seyretmektedir [10]. Mevsimsel değişim sürecinden etkilenen su kütlelerinde alansal ve hacimsel değişimler meydana gelmektedir $[6,11]$. Değişimde kuraklık ve yağış sulak alanlar üzerinde baskı oluşturan en önemli faktörlerdir. $\mathrm{Bu}$ nedenle su kaynaklarına yönelik değişim analizlerinin gerekliliği ortaya çıkmıştır [1, 12].

Son zamanlarda sulak alanların önemi daha çok anlaşılmaya başlamış ve bu alanların korunması için ekolojik ve sosyoekonomik analizlere dayanan koruma programları geliştirilmiştir [13-16]. Beşerî etkenlerin de etkisinin görüldüğü sulak alanların hassas ekosistemler olmaları, bu alanların sürekli izlenmesi ve koruma çalışmalarının yapılmasını zorunlu kılmıştır $[1,6,17,18]$.
Sulak alanlardaki değişime etki eden en temel etken kuraklıktır. Kuraklık meteorolojik kökenli doğal ve yıkıcı bir afettir [19, 20]. Yeryüzüne suyun ulaşmasında önemli bileşen olan yağışlardaki eksiklik meteorolojik kuraklık olarak ifade edilir [21]. Meteorolojik kuraklık sırasıyla hidrolojik, tarımsal ve sosyoekonomik kuraklığa neden olur [22]. Meteorolojik kuraklığın belirlenmesinde, sıcaklık, yağış ve nem gibi meteoroloji ve iklim verileri kullanılarak hesaplanan Standart Yağış İndisi (SPI), Palmer Kuraklık Şiddet İndeksi (PDSI) ve Normalin Yüzdesi İndeksi (PNI) gibi kuraklık indislerinden yararlanılmaktadır [19, 20, 23, 24]. Sulak alanlarda su yüzeyinde meydana gelen seviye değişimini açık yüzey buharlaşma metotları ile tek başına açıklamak yeterli olamayabilir. İçerdikleri bitki örtüsünde meydana gelen terleme olayı, sulak alanlardaki su miktarında meydana gelen değişime katkıda bulunur [11, 25]. Thornthwaite İklim Sinıflama Metodu sulak alanlardaki hidrolojik kuraklığın belirlenmesinde sıklıkla kullanılırken hem su yüzeyindeki buharlaşma hem de bitkilerden terleme yoluyla kaybolan su miktarını, diğer bir deyişle evapotranspirasyonu belirler [6, 11, 26-28].

Uzaktan Alg1lama (UA) doğal kaynakların izlenmesi, analizi, korunması ve yönetiminde önemli bir yere sahiptir [19, 29]. Su kaynaklarının izlenmesi, korunması ve yönetimi çalışmalarında, hidrometeorolojik ve hidrojeolojik yöntemlerin yanı sıra uzaktan algılama yöntemlerinden faydalanmak büyük avantajlar sağlar [29, 30]. Uzaktan Algılama algılayıcılarının, verilerinin ve yöntemlerinin sağladığı avantajların bazıları geniş sahaların tek seferde izlenebilmesi, kısa süre zarfında geleneksel yöntemlere göre daha hızlı sonuç üretilebilmesi, daha az iş gücü gerektirmesi, çok amaçlı ve farklı veri setlerini üretebilmesi şeklinde sıralanabilir [1, 6, 19, 29, 31, 32]. Sulak alanlardaki su ile kaplı alanların, su seviyesinin, kıyı çizgisinin, suyun kimyasal özelliklerinin mevcut durumunun ve çok zamanlı değişimlerinin belirlenmesi gibi pek çok konu uzaktan algilama yöntemleri ile araştırılmaktadır [1, 6, 22, 33-35].

Uydu görüntülerinden yararlanılarak suyla kaplı alanların diğer alanlardan sağlıklı olarak ayırt edilebilmesi ve su bileşenlerinin tanımlanması için geliştirilmiş su indisleri bulunmaktadır [27, 32, 36-39]. Uydu görüntülerinden oluşturulan su indisleri görüntüleri, herhangi bir yer ve zamanda meydana gelen kuraklığın izlenmesini mümkün kılar [40]. Normalize Fark Su İndisi (NDWI) [36] ve Modifiye Edilmiş Normalize Fark Su İndisi (MNDWI) [37] suyun görünür bölgedeki yüksek ve kızılötesi bölgedeki düşük yansıtımı dikkate alarak geliştirilmiş, su alanlarının tespiti için sıklıkla kullanılan ve başarılı sonuçlar veren indislerdir [6, 19, 22, 32]. Normalize su indisleri ile elde edilen verilerin kolay anlaşılır ve yorumlanabilir olması, diğer kaynaklardan temin edilen veriler 
ile entegrasyonda büyük kolaylık sağlar ve bu da etkili bir sulak alan yönetimindeki başarıyı arttırır [32, 22].

$\mathrm{Bu}$ çalışmada Çanakkale ili sınırları içerisinde bulunan Umurbey Deltasındaki sulak alanların yağışlı ve kurak dönemler sonundaki alansal ve zamansal değişimi belirlenmiş ve alansal değişim ile meteorolojik ve hidrolojik kuraklık verileri arasındaki ilişki incelenmiştir. Su ile kaplı alanların belirlenmesinde "Modifiye Edilmiş Normalize Fark Su İndisi" (MNDWI) kullanılmıştır. Meteorolojik ve hidrolojik koşullar SPI ve Thornthwaite yöntemleri ile tanımlanmış ve lagün su dinamiklerindeki değişim ile ilişkileri aylık ve mevsimlik (1 ve 3 ay) inceleme dönemlerinde değerlendirilmiştir.

\section{Materyal ve Metot}

\section{1. Çalışma Alanı}

Çalışma alanı, 26 $6^{\circ} 33^{\prime} 22^{\prime \prime}$ - 26 $6^{\circ} 57^{\prime} 1^{\prime \prime}$ doğu meridyenleri ile $40^{\circ} 7^{\prime} 52^{\prime \prime}-40^{\circ} 18^{\prime} 21 "$ kuzey paralelleri arasında ve Çanakkale ili, Umurbey beldesi sınırları içerisinde yer alan Umurbey Deltası'dır (Şekil 1). Yaklaşık 450 ha alan kaplayan ve deniz seviyesinden ortalama yüksekliği $3 \mathrm{~m}$ olan delta alanı, karasal sulak alan olup (Şekil 2b), kuş türlerinin beslenme, barınma ve üremeleri için önemli bir sahadır [41]. Delta, birçok küçük azmak içeren bataklık bir saha durumundadır [42]. Sahada yer alan azmak ve lagünler arasındaki en büyüğü Umurbey Lagün Gölü (Çatalazmak) olup, derinliği 50-75 cm civarındadır (Şekil 2c, 2d). Umurbey kıyılarında yer alan lagünlerin (Şekil 2e, 2f) alanı toplamda 206,71 ha'dır [43]. Derinliği fazla olmayan lagün alanlarının büyük bir kesiminde bitki ile su karma yapısı göze çarpmaktadır (Şekil 2a).
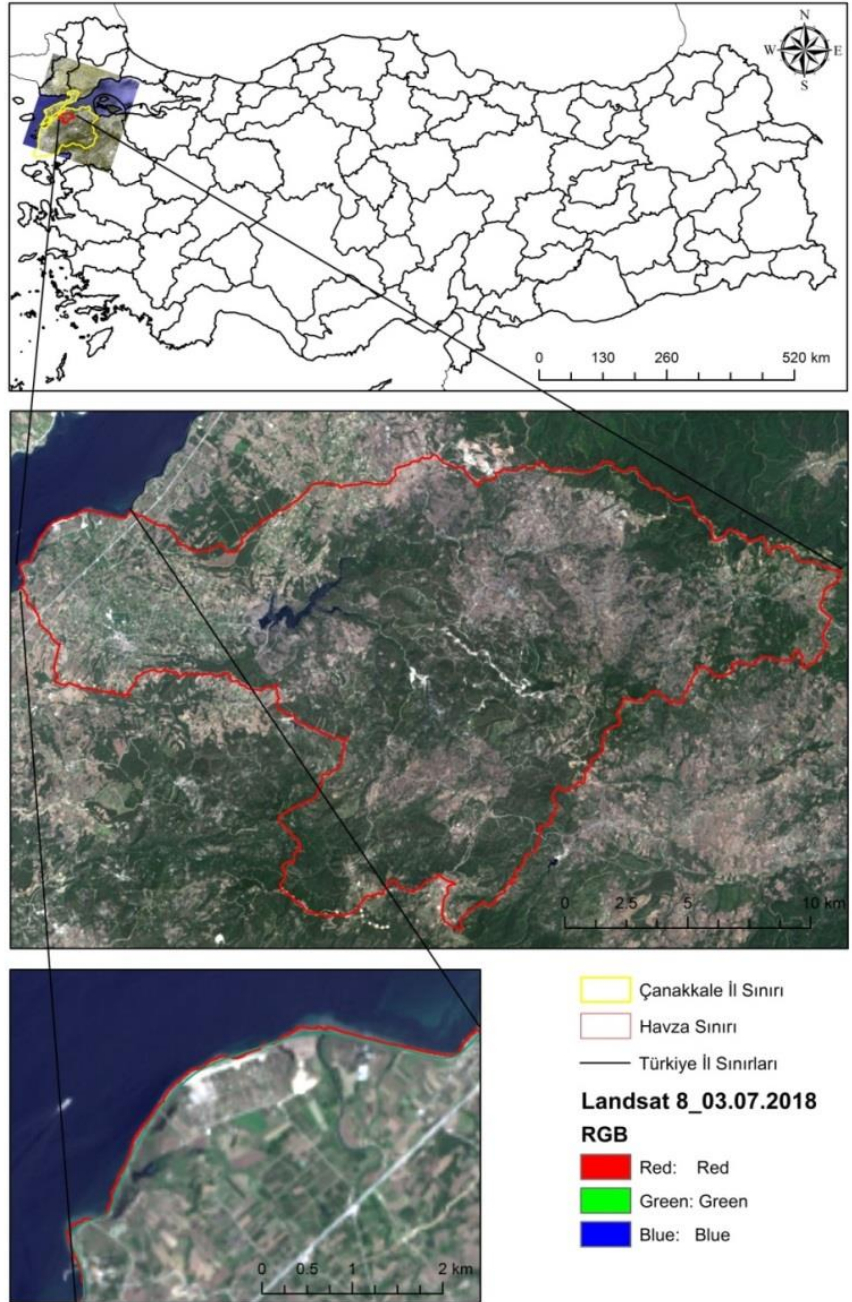

Şekil 1. Çalışma Alanı

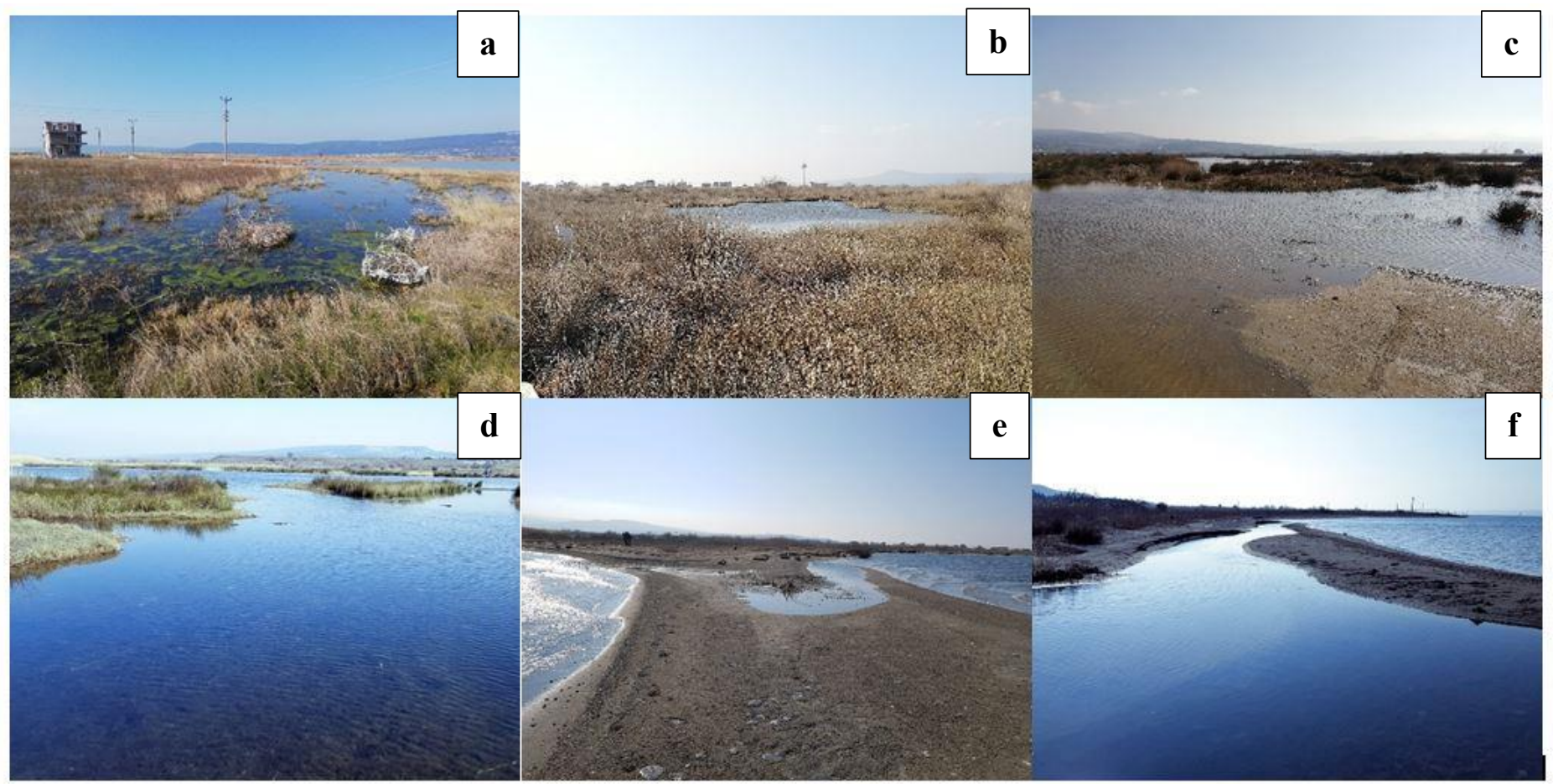

Şekil 2. Umurbey sulak alanında bitki+su karma yapısı (a), karasal sulak alan (b), sığ su alanları (c,d), Umurbey Deltası kıyı kesimi (e) lagün ile denizin birleştiği kesimler (f) (Foto: Derya Çakaroz, 10 Şubat 2019, Çanakkale) 


\subsection{Uzaktan Algılama Verisi ve Görüntü İşleme}

Umurbey Deltası'ndaki sulak alanların alansal değişimlerinin belirlenmesinde Birleşik Devletler Jeolojik Araştırma Kurumu (USGS) [44] 'den ücretsiz olarak temin edilen, 16 bit radyometrik ve $30 \mathrm{~m}$ ve $15 \mathrm{~m}$ mekânsal çözünürlüklü, 181/032 ve 182/032 (yol/sıra) numaralı Level 1-T Landsat-8 OLI (Operational Land Imager) multispektral uydu görüntüleri kullanılmıştır. Uzaktan algılama tabanlı değerlendirmeler, 2013-2019 yılları arasında 7 yağışlı ve kurak dönem hidrolojik döngüsüne ait toplam 14 adet görüntü ile yapılmıştır (Tablo 1). Uydu görüntülerindeki sistematik hataların giderilmesi ve atmosferdeki yutulma ve saçılma etkilerinin en aza indirilmesi için görüntülere, radyometrik kalibrasyon ve atmosferik düzeltme uygulanmıştır.

Tablo 1. Çalışmada kullanılan uydu görüntüleri

\begin{tabular}{|c|cc|c|c|}
\hline No & Görüntüleme Tarihi & Uydu & Yol/Sıra \\
\hline 1 & \multirow{2}{*}{2013} & 10.6 .2013 & Landsat 8 OLI & $182 / 032$ \\
2 & & 29.8 .2013 & Landsat 8 OLI & $182 / 032$ \\
3 & \multirow{2}{*}{2014} & 13.6 .2014 & Landsat 8 OLI & $182 / 032$ \\
4 & & 25.8 .2014 & Landsat 8 OLI & $181 / 032$ \\
5 & \multirow{2}{*}{2015} & 16.6 .2015 & Landsat 8 OLI & $182 / 032$ \\
6 & & 28.8 .2015 & Landsat 8 OLI & $181 / 032$ \\
7 & \multirow{2}{*}{2016} & 2.6 .2016 & Landsat 8 OLI & $182 / 032$ \\
8 & & 30.8 .2016 & Landsat 8 OLI & $182 / 032$ \\
9 & \multirow{2}{*}{2017} & 14.6 .2017 & Landsat 8 OLI & $181 / 032$ \\
10 & & 24.8 .2017 & Landsat 8 OLI & $182 / 032$ \\
11 & \multirow{2}{*}{2018} & 8.6 .2018 & Landsat 8 OLI & $182 / 032$ \\
12 & & 27.8 .2018 & Landsat 8 OLI & $182 / 032$ \\
13 & \multirow{3}{*}{2019} & 26.5 .2019 & Landsat 8 OLI & $182 / 032$ \\
14 & & 23.8 .2019 & Landsat 8 OLI & $181 / 032$ \\
\cline { 2 - 5 }
\end{tabular}

Umurbey Deltası'nda su ile kaplı alanların belirlenmesinde piksel boyutundan kaynaklı hataların giderilmesi amacıyla görüntülere füzyon yöntemlerinden NNDiffuse (Nearest Neighbor Diffusion Based Pansharpening) pankeskinleştirme [45] yöntemi uygulanmıştır [31]. NNDiffuse yöntemi kullanılarak, düşük mekansal çözünürlüklü multispektral bantlara $(30 \mathrm{~m})$, yüksek mekansal çözünürlüklü pankromatik bantlar (15m) füzyon edilerek, 15 m mekânsal çözünürlüğe sahip çok bantlı yeni görüntüler elde edilmiş ve sulak alanların tespiti için MNDWI kullanılmıştır.

Landsat uydu görüntüleri kullanılarak su kütlelerini belirlemek için üretilen ilk su indisi NDWI'dır. NDWI suyun, spektrumun yeşil bölgesindeki yüksek ve yakın kızılötesi (YKÖ) bölgesindeki düşük yansıtım özelliğini kullanarak oluşturulmuştur (1) [36]. NDWI -1 ile 1 arasında değer alır, 0 değerinin üstü suyu temsil eder ve aşağıdaki şekilde ifade edilir [36].

NDWI $=($ Yeşil Bölge - YKÖ) $/($ Yeşil Bölge + YKÖ $)$

Yakın kızılötesi (YKÖ) yerine kısa dalga kızılötesi bölgesi (KDKÖ) kullanılarak oluşturulan modifiye NDWI (MNDWI) ise suyun, elektromanyetik spektrumun yeşil bölgesindeki yüksek yansıtım ile kısa dalga kızılötesi (KDKÖ) bölgesindeki düşük e-ISSN: 2148-2683 yansıtımı arasındaki zıtlığı kullanır (2). MNDWI da -1 ile 1 arasında değer alır, genel olarak pozitif değerleri suyu ifade eder ve aşağıdaki şekilde formülize edilir [11, 31, 32, 37].

MNDWI = (Yeşil Bölge - KDKÖ) $/($ Yeşil Bölge + KDKÖ $)$

Çalışma sahasının özelliklerine göre değişiklik gösterse de sulak alanların diğer arazi kullanımı/örtüsü sınıflarından ayırt edilmesinde MNDWI'ın diğer indislere göre daha başarılı olduğu birçok çalışmada ispatlanmıştır $[1,6,11,37,46]$. MNDWI veri setleri Tablo 1'de gösterilen görüntüler üzerinden üretilmiştir. Yeşil bölge ve KDKÖ bölge bantları için Landsat 8 OLI'nin üçüncü (525-600 nm) ve altınc1 (1560-1660 nm) bantları kullanılmıştır. Ayrıca kuraklık verileri ile uyumlu olması için yağışlı dönem sonu (mayıs sonu - haziran başı) ve kurak dönem sonu (ağustos sonu - eylül başı) görüntüleri tercih edilmiştir. Sulak alanları belirlemek için belirlenmesi gereken MNDWI eşik değerleri manuel eşikleme (manual thresholding) yoluyla belirlenmiştir.

\subsection{Meteorolojik Veri ve İşlenmesi}

Çalışma kapsamında gerçekleştirilen meteorolojik ve hidrolojik kuraklık incelemelerinde T.C. Orman ve Su İşleri Bakanlığı Meteoroloji Genel Müdürlüğü (MGM) Lapseki Meteoroloji İstasyonu'nda 2013-2019 yılları arasında elde edilmiş sıcaklık ve yağış verileri kullanılmıştır. İnceleme kapsamında kullanılan, Lapseki İstasyonu'nun belirli bir süre kapatılıp tekrar açılması veya ölçümlerin yapılmaması nedeni ile meteorolojik verilerde bütünlük sağlanamamıştır. 2014 itibariyle OMGİ sistemi ile tekrar ölçümlerin başlandığı Lapseki İstasyonu'nda kuraklığın belirlenmesinde yeterli uzunlukta veri olmaması sebebiyle 2013-2019 yılları arasındaki eksik verileri tamamlamak için $33 \mathrm{~km}$ uzaklıktaki ve boğazın aynı tarafındaki Çanakkale İstasyonu'na ait meteorolojik verilerden faydalanılmıştır.

\subsubsection{Standart Yağış İndisi (SPI)}

Meteorolojik kuraklık şiddetinin değişimini belirlemek amacıyla, sadece yağış verisi ile güvenilir, kolay ve hızlı bir şekilde hesaplama yapan SPI [24, 47-49] kullanılmıştır. SPI, belli bir dönemin iklim değerlerinin uzun y1llara ait iklim değerlerinden sapma miktarını 1, 3, 6, 9 ve 12 aylık dönemler şeklinde belirleyebilir $[22,48,49]$ ve bu sapma aşağıdaki formül ile hesaplanır [47].

$$
\mathrm{SPI}=\left(\mathrm{X}_{\mathrm{i}}-\mathrm{X}_{\mathrm{ort}}\right) / \sigma
$$

Formülde belirtilen " $\mathrm{X}_{\mathrm{i}}$ " incelenen dönemdeki toplam yağ 1 şı $(\mathrm{mm})$, " $\mathrm{X}_{\text {ort }}$ " toplam yağış uzun yıllar ortalamasını $(\mathrm{mm})$ ve " $\sigma$ " ise toplam yağışın uzun yıllar standart sapmasını (3) ifade etmekte, hesaplanan SPI incelenen dönemdeki hidrometeorolojik yağışın uzun yıllardaki seyrinden farklılaşmasını ortaya koymaktadır. SPI hesaplaması sonucunda elde edilen negatif değerler kurak dönemi, pozitif değerler ise yağışl1-nemli dönemi ifade etmektedir [24, 48, 50, 51] (Tablo 1). 
Tablo 2. SPI değerleri ve sınıflandırılması [23]

\begin{tabular}{|c|c|}
\hline SPI değerleri & Kuraklık Kategorisi \\
\hline$\geq 2$ & Olağanüstü Nemli \\
\hline $1,60 \sim 1,99$ & Aşırı Nemli \\
\hline $1,30 \sim 1,59$ & Çok Nemli \\
\hline $0,80 \sim 1,29$ & Orta Nemli \\
\hline $0,51 \sim 0,79$ & Hafif Nemli \\
\hline $0,50 \sim-0,50$ & Normal Civarı \\
\hline$-0,51 \sim-0,79$ & Hafif Kurak \\
\hline$-0,80 \sim-1,29$ & Orta Kurak \\
\hline$-1,30 \sim-1,59$ & Şiddetli Kurak \\
\hline$-1,60 \sim-1,99$ & Çok Şiddetli Kurak \\
\hline$\leq-2$ & Olağanüstü Kurak \\
\hline
\end{tabular}

Bu çalışmada, SPI, açık kodlu bir istatistik programlama dili olan R ile de hesaplanmıştır. SPI hesaplamasında log-Logistic, Gamma veya PearsonIII dağılım fonksiyonlarından biri kullanılmaktadır. R, SPI için "Gamma" dağılım fonksiyonundan sonra bir değişkeni, ortalamayı 0 ve standart sapmayı 1 alarak, standart Gauss değişkenine dönüştürmektedir $[52,53]$. Çalışmada Lapseki İstasyonu'ndan sağlanan yağış verileri kullanılarak R programının SPI modülü ile aylık ve mevsimlik (1 ve 3 aylık) SPI değerleri hesaplanmıştır.

\subsubsection{Thornthwaite Iklim Sinıflama Metodu}

Sulak alanlar bitki ile su karma yapısı nedeniyle buharlaşma ve terlemeyi birlikte ifade eden evapotranspirasyon olayının etkisindedir [54]. Evapotranspirasyon ile su kaybının hesaplanmasında Thornthwaite İklim Sınıflandırması en çok tercih edilen yöntemlerden biridir [28, 6]. Thornthwaite metodu, sıcaklık ve yağış verileri kullanılarak hesaplanan evapotranspirasyon kaybına dayanılarak, yıl içerisinde toprakta birikmiş su, birikmiş rezerv suyun aylık değişimi, yıllık gerçek evapotranspirasyon, su fazlası ve su noksanı, akış ile su bütçesi hesaplanmaktadır $[6,11,54-56]$. Uç iklim koşullarında (kurak ve aşırı nemli) tatmin edici sonuç vermediği belirtilen Thornthwaite metodu [11, 57], Çanakkale'de 1lıman bir iklim yaşanmasından dolayı tercih edilmiş ve aşağıdaki işlem adımları $[54,58,11]$ ile SPI ile uyumlu olması için aylık ve mevsimlik (1 ve 3 aylık) dönemlerde hesaplanmıştır.

$\mathrm{I}_{\mathrm{i}}=\left(\frac{\mathrm{T}_{\mathrm{i}}}{5}\right)^{1,514} \rightarrow \mathrm{J}=\sum_{\mathrm{k}=1}^{12} \mathrm{I}_{\mathrm{i}} \rightarrow \mathrm{ET}_{\mathrm{p}}=16 \times\left(\frac{10 \times \mathrm{T}_{\mathrm{i}}}{\mathrm{J}}\right)^{\mathrm{c}} \times \mathrm{K}$

$\mathrm{c}=\left(0,000000675 \times \mathrm{J}^{3}\right)-\left(0,000077 \times \mathrm{J}^{2}\right)+(0,01792 \times$

J) $+0,49239$

Thornthwaite metodu denklemlerinde; $\mathrm{I}_{\mathrm{i}}$ aylık sicaklık indisini, $\mathrm{T}$ aylık ortalama sicaklığ $\left({ }^{\circ} \mathrm{C}\right), \mathrm{J}$ o y1la ait sicaklık indisini, $\mathrm{ET}_{\mathrm{P}}$ potansiyel evapotranspirasyonu (mm/ay), c katsayıyı ve K bulunan enleme göre Thornthwaite çizelgesinden okunan düzeltme katsayısını $(4,5)$ ifade eder.

Aylık $\mathrm{ET}_{\mathrm{P}}$ hesaplandıktan sonra gerçek evapotranspirasyon $\mathrm{ET}_{\mathrm{R}}$ ve su bilançosu aşağıdaki şekilde hesaplanır $[54,58,11]$.

I. Eğer ilgili ayın yağış miktarı $>\mathrm{ET}_{\mathrm{P}}$ :

a. $\mathrm{ET}_{\mathrm{P}}=\mathrm{ET}_{\mathrm{R}}$,

b. Yağış ile $\mathrm{ET}_{\mathrm{P}}$ arasındaki fark azaldıkça zemin rezervi azalır,

c. Zemin rezervi \%100'e ulaşınca su fazlası akışa geçer.

II. Eğer ilgili ayın yağış miktarı $<\mathrm{ET}_{\mathrm{P}}$ :

a. $\mathrm{ET}_{\mathrm{R}}$, yağ 1 ş ile zemin rezervinin bir kısmının veya tamamının toplamına eşittir

b. Zemin rezervi $=0$ olunca $\mathrm{ET}_{\mathrm{R}}$ yağış miktarına eşit olur.

III. $\mathrm{ET}_{\mathrm{P}}$ ile $\mathrm{ET}_{\mathrm{R}}$ arasındaki fark su noksanı olarak tanımlanır.

IV. Zemin rezervi başlangıçta \%100 kabul edilir ve üstündeki miktar su fazlası olarak tanımlanır.

Hesaplanan su bilanço çizelgesi aracılığıyla iklim tipi belirlenmektedir. Thornthwaite İklim Sınıflandırmasında, ilk aşamayı oluşturan Yağış Etkinlik İndisi aşağıdaki formül ile hesaplanır [59]:

$$
\operatorname{Im}=(100 s-60 d) / n
$$

formülde, (lm) yağış etkinlik indeksi, (s) yıllık su fazlası, (d) y1llık su noksanı, (n) ise yıllık potansiyel evapotranspirasyonu (6) ifade etmektedir. Thornthwaite, yağış ve evapotranspirasyon arasındaki ilișkiye dayanarak iklimleri nemli ve kurak olmak üzere iki sınıfa, daha sonrasında nemli ve kurak iklimleri kendi içerisinde ayırmıştır [59]. Yağış etkinlik indisine göre E, D, C1 kurak alanları tanımlarken C2, B1, B2, B3, B4 ve A nemli sahaları işaret etmektedir (Tablo 3).

Tablo 3. Yağış Etkinlik İndis Değerleri ve Sınıflandırılması [59]

\begin{tabular}{|c|c|c|c|}
\hline Sembol & İklim Tipi & $\begin{array}{c}\text { Yağıss Etkinlik } \\
\text { İndisi }\end{array}$ & $\begin{array}{c}\text { Genel Nemlilik } \\
\text { Tipi }\end{array}$ \\
\hline $\mathbf{A}$ & Çok Nemli & $>100$ & \multirow{6}{*}{ Nemli İklimler } \\
\hline B4 & Nemli & $80-100$ & \\
\hline B3 & Nemli & $60-80$ & \\
\hline B2 & Nemli & $40-60$ & \\
\hline B1 & Nemli & $20-40$ & \\
\hline $\mathrm{C2}$ & Yarı Nemli & $0-20$ & \\
\hline C1 & $\begin{array}{c}\text { Kurak-Yarı } \\
\text { Nemli }\end{array}$ & $(-20)-0$ & \multirow{3}{*}{ Kurak İklimler } \\
\hline D & Yarı Kurak & $(-40)-(-20)$ & \\
\hline $\mathbf{E}$ & Kurak & $<-40$ & \\
\hline
\end{tabular}

Sınıflandırmanın ikinci aşamasında Sıcaklık Etkinlik İndisi, y1llı toplam potansiyel evapotranspirasyon değerine göre belirlenir [59]. 
Tablo 4. Sıcaklık Etkinlik İndis Değerleri ve Sınıflandırılması [59]

\begin{tabular}{|c|c|c|c|}
\hline Sembol & İklim Tipi & Sıcaklık Etkinlik İndisi & Genel Nemlilik Tipi \\
\hline $\mathbf{A}^{\prime}$ & Megatermal & $>1140$ & \multirow[t]{2}{*}{ Yüksek Sicaklıktaki İklimler } \\
\hline$B^{\prime} 4$ & 4. Dereceden Mezotermal & $997-1140$ & \\
\hline$B^{\prime} \mathbf{3}$ & 3. Dereceden Mezotermal & $855-997$ & \multirow[t]{2}{*}{ Orta Sıcaklıktaki İklimler } \\
\hline $\mathbf{B}^{\prime} \mathbf{2}$ & 2. Dereceden Mezotermal & $712-855$ & \\
\hline B'1 $^{\prime}$ & 1. Dereceden Mezotermal & $570-712$ & \multirow{2}{*}{ Düşük Sıcaklıktaki İklimler } \\
\hline$C^{\prime} 2$ & 2. Dereceden Mikrotermal & $427-570$ & \\
\hline$C^{\prime} 1$ & 1. Dereceden Mikrotermal & $285-427$ & \multirow{3}{*}{ Çok Düşük Sıcaklıktaki İklimler } \\
\hline $\mathbf{D}^{\prime}$ & Tundra & $142-285$ & \\
\hline $\mathbf{E}^{\prime}$ & Don & $<142$ & \\
\hline
\end{tabular}

Üçüncü aşamada, kurak iklimler için nemlilik indisi (Ia), nemli iklimler için kuraklık indisi (Ih) hesaplanarak, ilgili bölgenin nemlilik - kuraklık derecesi belirlenir. Hesaplamada " $n$ " yıllık potansiyel evapotranspirasyonu "d" yıllık toplam su noksanını, "s" ise yıllık su fazlasını (7) ifade etmektedir. Her nokta ya da istasyon için kuraklık ve nemlilik indislerinden sadece biri hesaplanmalıdır [59].

$$
\text { Ia }=100 \mathrm{~d} / \mathrm{n} \quad \mathrm{Ih}=100 \mathrm{~s} / \mathrm{n}
$$

Tablo 5. Kuraklık-Nemlilik İndis Değerleri ve Sınıflandırılması [59]

\begin{tabular}{|c|c|c|c|c|c|}
\hline \multicolumn{3}{|c|}{ Nemli İklimler } & \multicolumn{3}{c|}{ Kurak İklimler } \\
\hline Sembol & Tali İklim Tipi & Ia & Sembol & Tali İklim Tipi & Ih \\
\hline R & Su Noksanı Yok veya Az & $0-16,7$ & d & Su Fazlası Yok veya Az & $0-10$ \\
\hline S & Yazın Orta Derecede Su Noksanı & $16,8-33,3$ & s & Yazın Orta Derecede Su Fazlası & $11-20$ \\
\hline W & Kışın Orta Derecede Su Noksanı & $16,8-33,3$ & w & Kışın Orta Derecede Su Fazlası & $11-20$ \\
\hline s2 & Yazın Şiddetli Su Noksanı & $>33,4$ & s2 & Yazın Şiddetli Su Fazlası & $>21$ \\
\hline w2 & Kışın Şiddetli Su Noksanı & $>33,4$ & w2 & Kışın Şiddetli Su Fazlası & $>21$ \\
\hline
\end{tabular}

Son olarak dördüncü aşamada, denizsellik ve karasallık oranı (PE oranı) belirlenmektedir [59]. En sıcak üç ayın potansiyel evapotranspirasyonunun yıllı potansiyel evapotranspirasyona oraniyla elde edilmektedir [59].

$$
\text { PE Oranı }=(\text { make1 }+ \text { make } 2+\text { make } 3) / \mathrm{n}
$$

make 1, make 2 ve make 3 en yüksek aylık potansiyel evapotranspirasyonu, $\mathrm{n}$ ise ylllk potansiyel evapotranspirasyonu (8) ifade etmektedir.

Tablo 6. Denizellik-Karasallık İndis Değerleri ve Sinıflandırılması [59]

\begin{tabular}{|c|c|c|}
\hline Sembol & PE Oranı $\%$ & Tali İklim Tipi \\
\hline $\mathbf{a}^{\prime}$ & $<48$ & Tam Denizel \\
\hline $\mathbf{b}^{\prime} \mathbf{4}$ & $48-51,9$ & Denizel \\
\hline $\mathbf{b}^{\prime} \mathbf{3}$ & $52,0-56,3$ & Yarı Denizel \\
\hline $\mathbf{b}^{\prime} \mathbf{2}$ & $56,4-61,6$ & Hafif Denizel \\
\hline $\mathbf{b}^{\prime} \mathbf{1}$ & $61,7-68,0$ & Hafif Karasal \\
\hline $\mathbf{c}^{\prime} \mathbf{2}$ & $68,1-76,3$ & Yarı Karasal \\
\hline $\mathbf{c}^{\prime} \mathbf{1}$ & $76,3-88,0$ & Karasal \\
\hline $\mathbf{d}^{\prime}$ & $>88,1$ & Şiddetli Karasal \\
\hline
\end{tabular}

\subsection{Veri Analizi}

2013 ve 2019 yılları arasında yağışlı ve kurak dönem sonlarında elde edilen uydu görüntülerinden (Tablo 1) MNDWI su indisi kullanılarak elde edilen 14 su ile kaplı alan verisi ile aynı dönemlere ait SPI ve Thornthwaite verileri arasındaki ilişki, korelasyon-regresyon analizi ile incelenmiştir. Uzaktan algılama ve hidrometeorolojik veri setleri arasındaki ilişkiyi ifade etmek için Pearson korelasyon katsayısı $(\mathrm{R})$, belirleme katsayısı $\left(\mathrm{R}^{2}\right)$ kullanılmıştır.

\section{Araştırma Sonuçları ve Tartışma}

\section{1. İklim Özellikleri}

Lapseki MGM İstasyonu'nun 1986-2019 yılları arasındaki verilerine göre Karadeniz ikliminden Akdeniz iklimine geçiş özelliği gösteren Marmara ikliminin etkisi altındaki Umurbey'in uzun yıllar ortalama sıcaklığı $13,9^{\circ} \mathrm{C}$ 'dir. En soğuk ay ortalama $5,5^{\circ} \mathrm{C}$ ile Ocak iken, en sicak ay ortalama $25,1^{\circ} \mathrm{C}$ ile Ağustos ayında yaşanır (Şekil 4). Yıllık toplam yağış $648 \mathrm{~mm}$ 'dir. Ortalama yağışlar Ağustos'da $10 \mathrm{~mm}$ civarında en düşük, Aralık'ta ise en yüksektir $110 \mathrm{~mm}$ seviyelerindedir (Şekil 3). Bölgede y1l içerisinde hâkim rüzgâr yönü kuzeydoğu (KD) ve ikinci yön ise güneybatıdır (GB). Kuzey yönlü rüzgârlar sıcaklıkların düşmesine neden olur iken, güneyden esen rüzgârlar da bölgeye yağış getirmektedir [50]. 


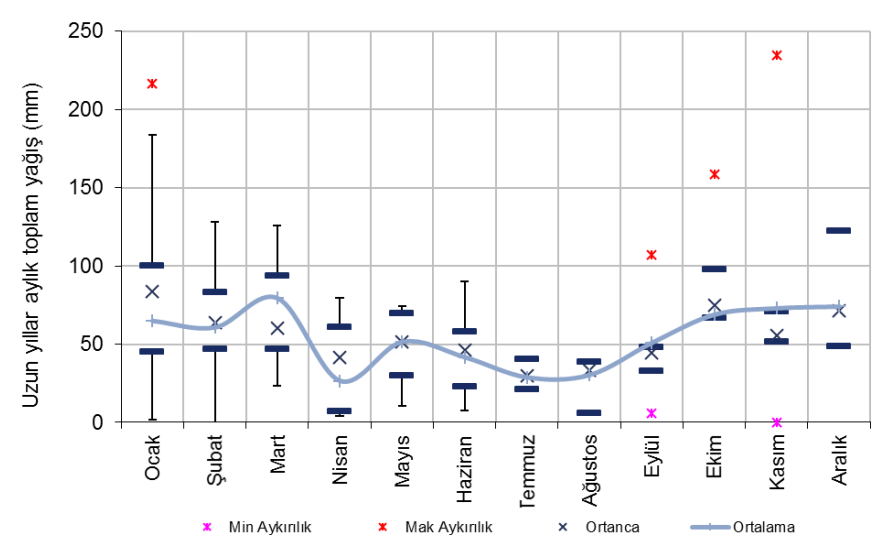

Şekil 3. Uzun yıllar aylık toplam yağış kutu grafiği

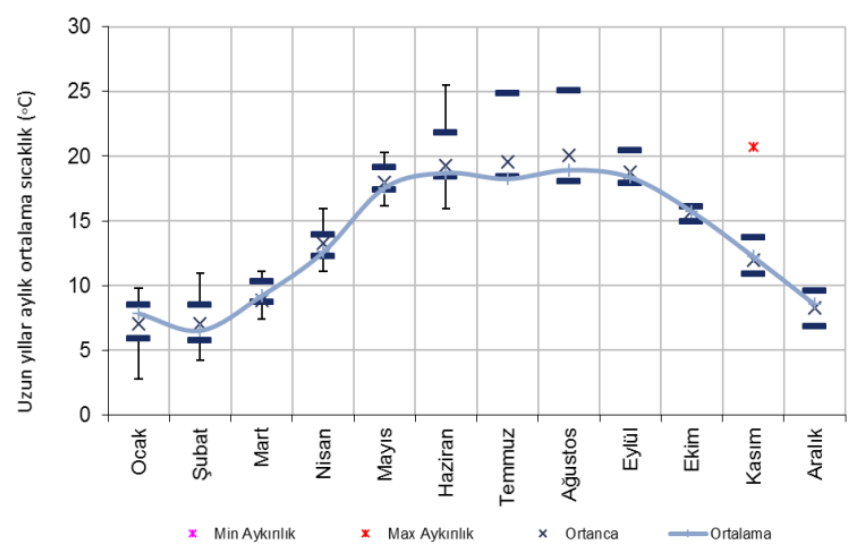

Şekil 4. Uzun yıllar aylık ortalama sıcaklık kutu grafiği

\subsection{Uzaktan Algılama Bulguları}

Çalışma alanındaki su varlığı 2013-2019 yılları arasındaki Landsat uydu görüntülerine uygulanan MNDWI su indisi ile belirlenmiştir. Her ne kadar genel olarak MNDWI için 0'dan büyük değerler suyu ifade etse de suyun içeriğine göre bu değer değişebilmekte ve su kütleleri 0 'ın altı veya üstü değerler alabilmektedir [37, 38, 60,61]. Bu çalışmada her görüntü için manuel olarak belirlenen eşik değerlerin ortalaması yağışlı dönem sonu için $-0,03$ iken kurak dönem sonu için 0,03'tür. Eşik değerlerinin 0'dan farklı olmasının en belirgin nedeni çalışma alanındaki sulak alanlardaki su kütlesi dışında bolca bitki ve toprak içeren karma arazi örtüsü yapısının varlığıdır.

Elde edilen bulgulara göre sulak alandaki su varlığı, 2013 'ten 2019'a kadar hem yağışlı dönem hem de kurak dönem sonunda azalma eğilimindedir (Şekil 5, Şekil 6). 2013-2019 yılları arasında, yağışlı dönem sonlarındaki su kaplı alan 0,11-
$0,22 \mathrm{~km}^{2}$, kurak dönem sonlarındaki su kaplı alan $0,08-0,17 \mathrm{~km}^{2}$ arasındadır. Yağışlı dönem sonlarında su ile kaplı alanların ortalama ve standart sapma değerleri sirasiyla $0,16 \mathrm{~km}^{2}$ ve 0,04 $\mathrm{km}^{2}$, kurak dönem sonlarında ise $0,12 \mathrm{~km}^{2}$ ve $0,03 \mathrm{~km}^{2}$ dir. Yağışlı dönem sonlarında en geniş ve en dar su alanları $0,22 \mathrm{~km}^{2}$ ile 2013 ve $0,11 \mathrm{~km}^{2}$ ile 2019 yıllarında oluşmuştur. Kurak dönem sonlarında ise en geniş ve dar su ile kaplı alanlar 0,17 $\mathrm{km}^{2}$ ile 2014 ve $0,08 \mathrm{~km}^{2}$ ile 2019 yıllarında oluşmuştur.

Yağışlı ve kurak dönemlerdeki su kaplı alanların mutlak farkının ortalamasının $0,04 \mathrm{~km}^{2}$ ve standart sapmalarındaki farkın ortalamasının ise $0,003 \mathrm{~km}^{2}$ gibi düşük değerlerde olması, çalışma alanı olan sulak alanın yaz mevsiminde yaşanan doğal kuraklık baskısından (yağış eksikliği ve yüksek evapotranspirasyon ile su kaybı) çok fazla etkilenmediğini, değişimin yatay yönden ziyade düssey yönde meydana geldiğini göstermektedir.

Kurak dönemlerde bitkilerin varlığ 1 nedeniyle, lagün alanlarının MNDWI değerinin düşük olması beklenmektedir.. Ancak sulak alanın doğal yapısındaki bitki+su yapısından dolayı bu alanlar da sulak alanın içine dahil edilmiştir. Ancak çalışma alanında 2014, 2015, 2017 ve 2019 yıllarına ait değerler birbirine çok yakındır. Burada yağışlı ve kurak dönem sonunda hem sulak alanın kapladığ alan hem de MNDWI sonucu elde edilen alan farkı oluştuğundan, yer altı ve yer üstü beslenimin ve kurak dönem etkisi ile kar yağış eksikliğinin alan üzerinde ortalamanın altında bir etkiye sahip olması nedeniyle farkın az olduğunu, ancak lagünlerde hem düşey hem de yatayda değişimin meydana geldiğini söyleyebiliriz. Diğer taraftan $15 \mathrm{~m}$ mekânsal çözünürlüklü Landsat uydu görüntüleri pankeskinleştirme ile çözünürlüğü arttırıldığı ve multispektrali $30 \mathrm{~m}$ olduğu için su ile bitki ayrımını yapmada yetersiz kalıyor olabilir. $\mathrm{Bu}$ durum incelenen iki dönem sonunda su alanı değerlerinin birbirine yakın çıkmasının nedeni olabilir.

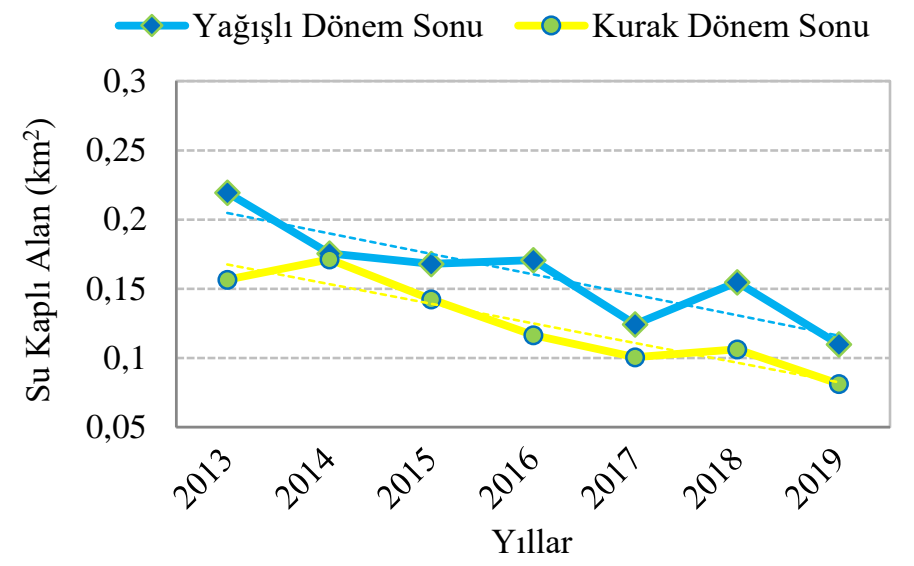

Şekil 5. Yağışlı ve kurak dönemlerin sonunda MNDWI ile belirlenen su ile kaplı alanların zamansal değişiminin grafiksel gösterimi 
European Journal of Science and Technology
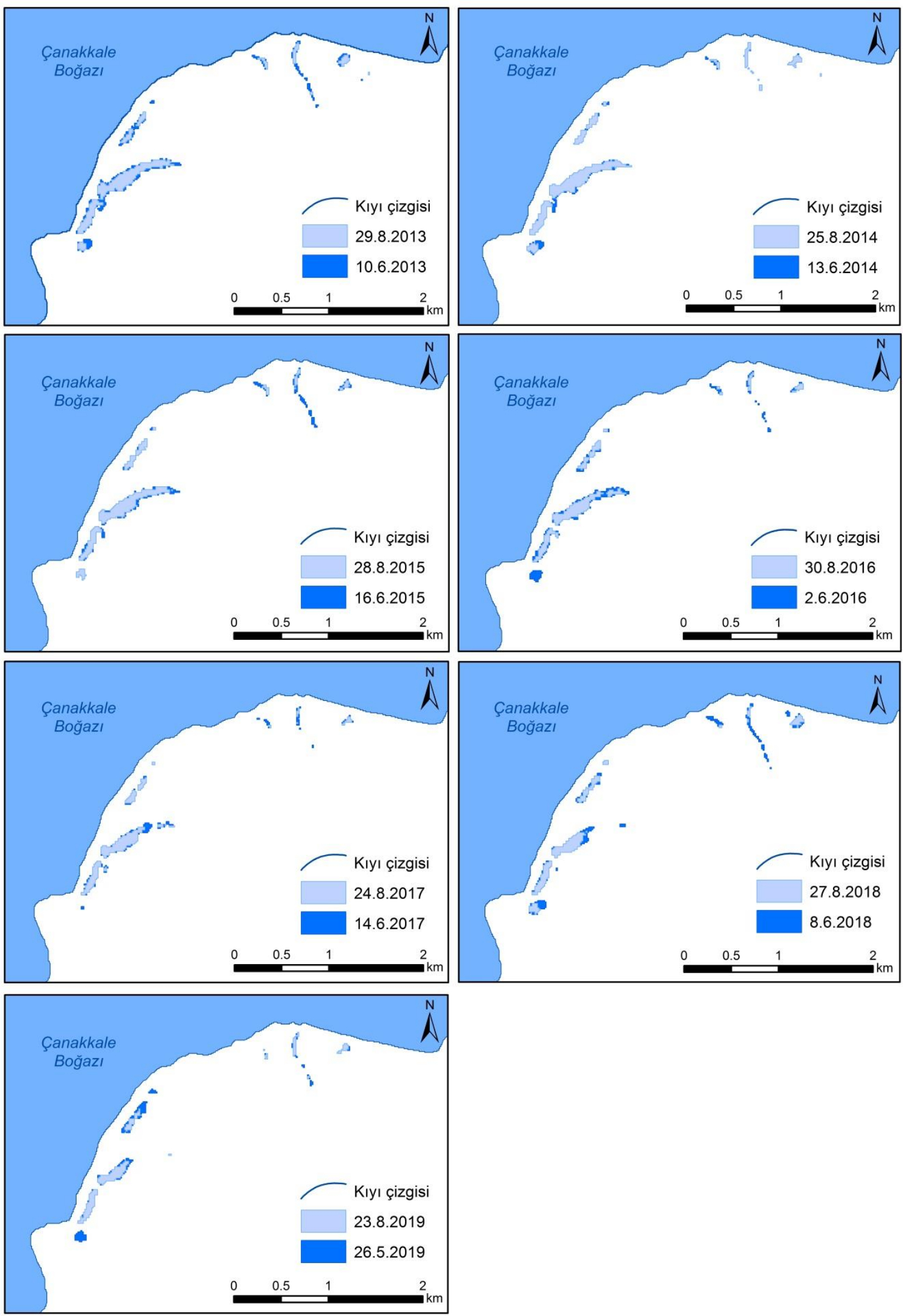

Şekil 6. Yağışlı ve kurak dönemlerin sonunda MNDWI ile belirlenen su ile kaplı alanların zamansal değişimi 


\subsection{Kuraklık Bulguları}

Çalışma sahasında 2013-2019 yılları arasındaki meteorolojik değerlendirmeler, SPI ve Thornthwaite yöntemleri kullanılarak her bir yıl için 1 aylık ve 3 aylık (mevsimlik) dönemler şeklinde gerçekleştirilmiştir. Yağışlı ve kurak dönem sonlarında MNDWI ile elde edilen su ile kaplı alanlar, SPI ve Thornthwaite yöntemlerinin sonuçları ile ilişkilendirilmiştir.

\subsubsection{Standart Yağı İ Indisi (SPI)}

2013-2019 yılları arasında her bir yıl için 1 ve 3 aylık dönemler şeklinde değerlendirilen SPI sonuçları Şekil 7'de görselleştirilmiştir. 1 aylık SPI indis sonuçlarına göre, 2013 ve 2015 yıllarının Aralık ayında sirası ile -2,02 ve -3,22, 2014 yılının ise Şubat ayında $-2,73$ SPI ile olağanüstü kurak bir dönem yaşanmıştır. 2014 yılı Haziran ayı (1,73), 2016 Kasım (1,95), 2017 Ocak $(1,69)$ ve 2019 Temmuz ayında $(1,71)$ aşırı nemli dönemler yaşanırken, 2017 yılının Nisan ayı $(-1,77)$ çok şiddetli kurak geçmiştir. Yağışlı dönem sonu olan Mayıs ve kurak dönem sonu olan Ağustos ayları değerlendirildiğinde,
2013 ve 2015 yılları sirası ile $-0,76$ ve $-0,78$ değerleri ile hafif kurak, 2014, 2017 ve 2019 yılları sirası ile 0,24, -0,24 ve $-0,13$ değerleri ile normal civarında, 2016 ve 2018 Mayıs aylarında 1,06 ve 0,86 değerleri ile orta nemli dönemler yaşanmıştır. Ağustos dönemleri ise 2013 ve 2016 y1lları sırasılyla $-0,65$ ve 0,51 ile hafif kurak, 2014 ve 2019 y1llar1 $(0,81$ ve 0,91$)$ orta nemli, 2015, 2017 ve 2018 yıllarında sirasiyla $0,28,0,10$ ve 0,34 değerleri ile orta nemli geçmiştir.

3 aylık SPI indis sonuçlarına bakıldığında; k1ş mevsimlerinde 2013 yılı 1,80 ile aşırı nemli, 2014 yılı -2,00 ile olağanüstü kurak geçmiştir. Diğer yıllarda ise orta ve hafif nemli dönemler yaşanmıştır. Sonbahar mevsiminde en kurak yıl $(-1,22)$ orta kurak sınıfinda 2019 yılı, 1,22 değeri ile en nemli y1lı ise 2016'dir. İlkbahar mevsiminde, genel olarak orta nemli ve normal civarında SPI sınıfları görülürken, en nemli yıl 1,03 değeri ile orta nemli sınıfında olan 2014, -1,82 değeri ile çok şiddetli kuraklık sınıfında değerlendirilen yıl ise 2017'dir. Son olarak yaz mevsiminde, hafif ve orta nemli dönemler birbirini takip etmiş, 1,94 değeri ile 2014 yılı aşırı nemli, -1,09 değeri ile de 2016 yılında orta kurak bir dönem yaşanmıştır.
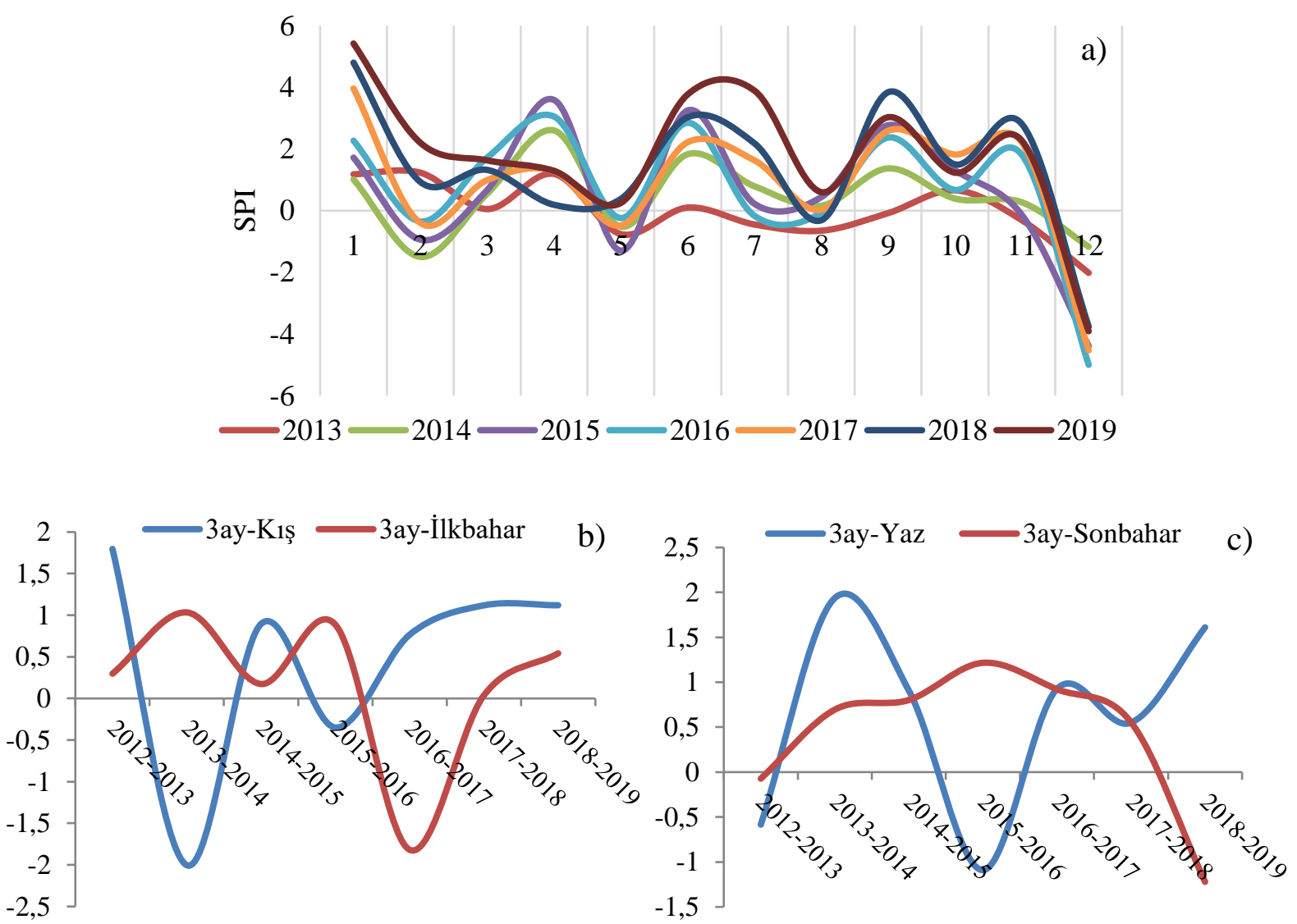

Şekil 7. 1 aylık dönem incelemesi (a), 2013-2019 yılları arasında SPI değişiminin 3 aylık dönem incelemesi (b, c)

\subsubsection{Thornthwaite Su Bütçesi ve İklim Sınıflaması}

Potansiyel ve gerçek evapotranspirasyon değerleri, 19852019 (34 yıl) aralı̆̆ındaki yıllık veriler esas alınarak Thornthwaite yöntemi ile hesaplanmıştır. Bu yönteme göre Lapseki'de yıllık $\mathrm{ET}_{\mathrm{P}}$ toplamı 799,5 mm, yıllık $\mathrm{ET}_{\mathrm{R}}$ toplamı ise 385,8 mm'dir. Ekim ayının başından Mayıs ayına kadar yağış $\mathrm{ET}_{\mathrm{P}}$ 'den fazladır. $100 \mathrm{~mm}$ kabul edilen zemin rezervi Nisan ayının sonundan itibaren Mayıs sonuna kadar harcanır. Haziran ayı ortasından Eylül ayının sonuna kadar su noksanlığ görülmektedir. $100 \mathrm{~mm}$ 'lik zemin rezervi Ekim ayı itibariyle dolmaya başlar ve Aralık ayında tamamlanır. Aralık ayı ve bir sonraki yılın Nisan ayı sonuna kadar zemin rezervi $100 \mathrm{~mm}$ dir. Mayıs ayı itibariyle yağışın $\mathrm{ET}_{\mathrm{R}}$ 'yi karşılayamaması ile zemin rezervinde azalma başlar. Lapseki'de yağışın $\mathrm{ET}_{\mathrm{R}}$ 'den fazla olduğu kış ve sonbahar aylarında $220,7 \mathrm{~mm} \mathrm{su}$ fazlası neticesinde iklim nemli seyir ederken, yağışın $\mathrm{ET}_{\mathrm{R}}$ 'den az 906 
olduğu Mayıs ve Eylül ayları arasında ise 413,6 mm su eksiği nedeniyle kurak şartların hakim olduğu görülmektedir. Sonuç olarak 606,5 mm'lik toplam yağışın, 385,8 mm'si buharlaşma ve terleme yoluyla tekrar atmosfere geri döner. Lapseki'nin iklim verilerine göre su bilançosu Tablo 7, ortalama yağış, $E T_{P}$ ve $E T_{R}$ aylık değişimi Şekil 8'de verilmiştir.

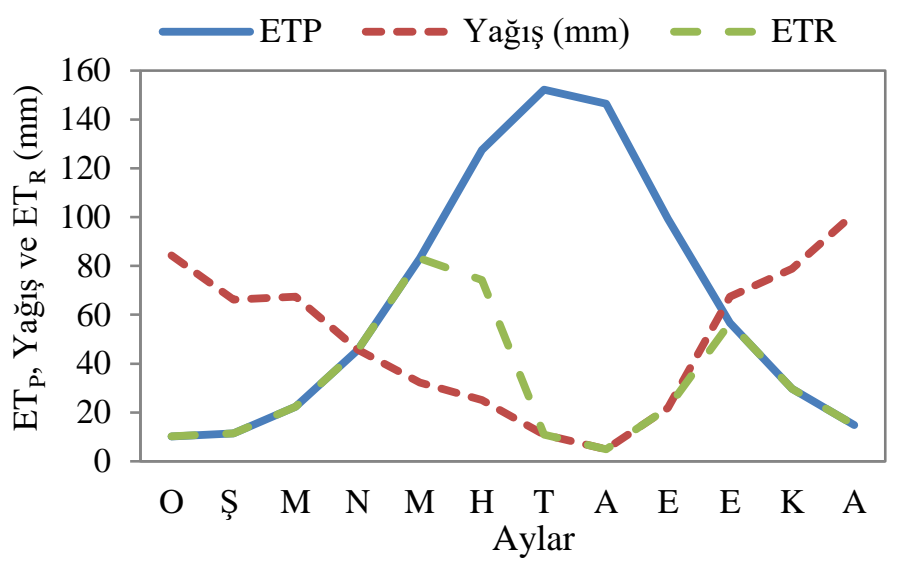

Şekil 8. Lapseki'nin ETP, Yağış ve ET ${ }_{R}$ Grafiği

Tablo 7. Lapseki’nin Su Bilançosu

\begin{tabular}{|c|c|c|c|c|c|c|c|c|c|c|c|c|c|}
\hline $\begin{array}{c}\text { İklim } \\
\text { Unsurları }\end{array}$ & Ocak & Şubat & Mart & Nisan & Mayıs & Haziran & Temmuz & Ăgustos & Eylül & Ekim & Kasım & Aralık & Yıllık \\
\hline Sıcaklık $\left({ }^{\circ} \mathbf{C}\right)$ & 5,93 & 5,99 & 8,52 & 12,55 & 17,37 & 22,21 & 25,10 & 25,57 & 21,31 & 16 & 11,41 & 7,66 & \\
\hline $\begin{array}{c}\text { Sıcaklık } \\
\text { Indisi }\end{array}$ & 1,29 & 1,31 & 2,24 & 4,03 & 6,59 & 9,56 & 11,51 & 11,83 & 8,98 & 5,82 & 3,49 & 1,91 & 68,56 \\
\hline ETp & 10,17 & 11,50 & 22,30 & 45,65 & 83,12 & 127,51 & 152,20 & 146,51 & 99,40 & 56,60 & 29,63 & 14,86 & 799,45 \\
\hline Enlem & 0,80 & 0,89 & 0,99 & 1,10 & 1,20 & 1,25 & 1,23 & 1,15 & 1,04 & 0,93 & 0,83 & 0,78 & \\
\hline Yağıs (mm) & 84,37 & 66,16 & 67,39 & 45,67 & 32,28 & 25,12 & 10,97 & 4,92 & 21,81 & 67,40 & 78,92 & 101,50 & 606,51 \\
\hline $\begin{array}{c}\text { Birikmiş } \\
\text { suyun aylk } \\
\text { değişmesi }\end{array}$ & 0 & 0 & 0 & 0 & $-50,84$ & $-49,16$ & 0 & 0 & 0 & 10,80 & 49,29 & 39,91 & \\
\hline Birikmiş su & 100 & 100 & 100 & 100 & 49,16 & 0 & 0 & 0 & 0 & 10,80 & 60,09 & 100 & \\
\hline ETr & 10,17 & 11,50 & 22,30 & 45,65 & 83,12 & 74,28 & 10,97 & 4,92 & 21,81 & 56,60 & 29,63 & 14,86 & 385,81 \\
\hline Su noksanı & 0 & 0 & 0 & 0 & 0 & $-53,23$ & $-141,22$ & $-141,59$ & $-77,58$ & 0 & 0 & 0 & 413,62 \\
\hline Su fazlası & 74,19 & 54,66 & 45,09 & 0,01 & 0 & 0 & 0 & 0 & 0 & 0 & 0 & 46,72 & 220,68 \\
\hline Akım & 48,78 & 51,72 & 48,41 & 24,21 & 24,21 & 0 & 0 & 0 & 0 & 0 & 0 & 23,36 & 220,68 \\
\hline
\end{tabular}

Hesaplanan su bilançosundan elde edilen değerler neticesinde Lapseki yağış etkinlik indisinden "Kurak-Yarı Nemli", sicaklık tesiri indisinden "2. dereceden Mezotermal", nemlilik indisinden "Kışın çok kuvvetli su fazlası" ve denizellikkarasallık oranından "yarı denizel" olduğundan Lapseki'nin iklim indisi "Kurak-Yarı nemli, 2. dereceden Mezotermal, kışın çok kuvvetli su fazlası, yarı denizel" olarak ifade edilir.

\subsection{Kuraklığın Alansal Değişim ile İlişkisi}

2013-2019 yılları arasında yağışı dönemde sulak alanların SPI ile kuvvetli ilişki olması, kurak dönemde ise su alanlarının $\mathrm{ET}_{\mathrm{P}}$ ile kuvvetli ilişki vermesi beklenmektedir. Bulgular bu doğrultuda değerlendirilecek olup, 1 ve 3 aylık (aylık ve mevsimlik) olarak incelenmiştir.

\subsubsection{Aylık Dönem İncelemesi}

Lagün alanında uzun yıllar içinde meteorolojik bileşenlerin su alanları üzerindeki farklı etkileri, bölgenin su bütçesinden ileri gelir. Özellikle su noksanlığı, bu etkinin ve anomalinin değişmesinde etkindir. Su noksanlığı 2013-2019 yılları arasında artma trendi içindedir. Ancak yıldan yıla artış ve azalış yani sinüzoidal dalga şeklinde bir davranış göstermektedir. Bu döngüde 2014-2015 yıllarında bir bozulma görülse de 20162019 yılları arasında çok daha kuvvetlidir (Şekil 9). 


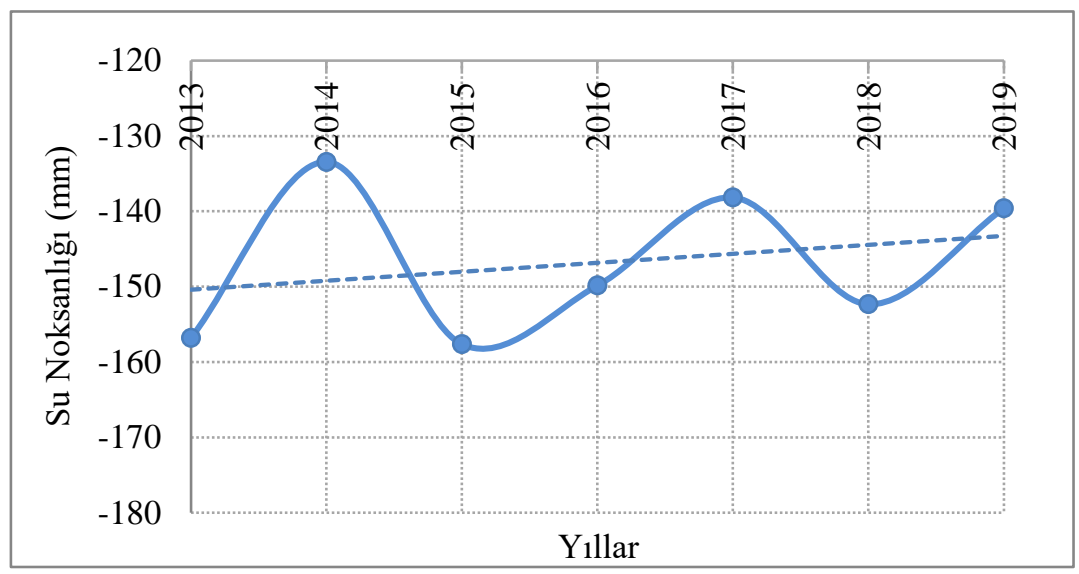

Şekil 9. 2013-2019 yılları arasında su noksanlı̆̆ eğilim grafiği

2013-2019 yılları arasında kurak dönemde su alanı ile SPI arasında, su alanında meydana gelen artışın aksine, SPI meteorolojik kuraklık değerlerinde bir azalma olup, polinomsal negatif bir ilişki vardır $\left(\mathrm{R}^{2}=0,608\right)$ (Şekil 10a). Diğer taraftan son dört yıllık dönemde 2016-2019 itibariyle SPI ve su alanları arasındaki ilişi daha anlamlı sonuçlar vermektedir $\left(\mathrm{R}^{2}=0,9775\right)$ (Şekil 10b). Bu ilișki 2014 ve 2015 yıllarındaki değerler ile bozulmaktadır. 2014 ve 2015 'te yağışa bağlı olarak kuraklığın artmasına rağmen, sıcaklık ve rüzgarın normalin altında gerçekleşmesinden dolayı, ET'nin düşük olmasına bağlı olarak beklenen korelasyonlar gerçekleşmez. 2013-2019 yılları arasında kurak dönemde potansiyel buharlaşmanın su alanlarındaki değişimde etkisi düşüktür $\left(\mathrm{R}^{2}=0,2571\right)$ (Şekil 10c). Kurak dönemde gerçek buharlaşma $\left(\mathrm{ET}_{\mathrm{R}}\right)$, tam anlamıyla yağışları yansıtır $\left(\mathrm{R}^{2}=0,99\right)$ (Şekil 10d). 2016-2019 yılları arasında gerçek buharlaşma arttıkça su kaplı alanların azaldığı görülür $\left(\mathrm{R}^{2}=0,9963\right)$ (Şekil 10f). Tüm bu incelemeler neticesinde ET'nin su alanları üzerindeki etkileri iki farklı davranış sergiler ve bu davranışlar 2013-2019 ve 2016-2019 dönemlerini kapsayacak şekilde iki farklı anomalilerde temsil edilir (Şekil 10c, 10e, 10f).

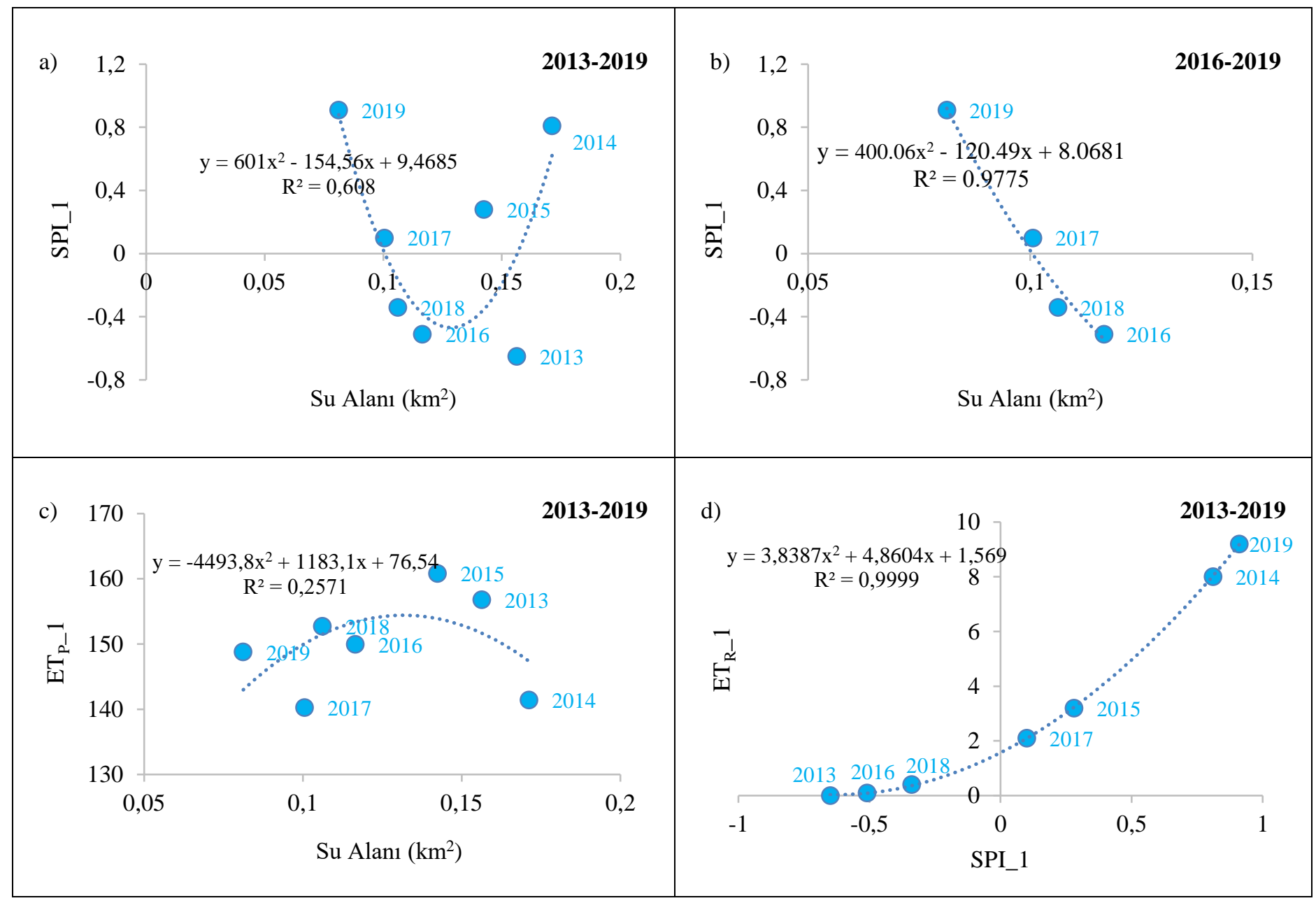




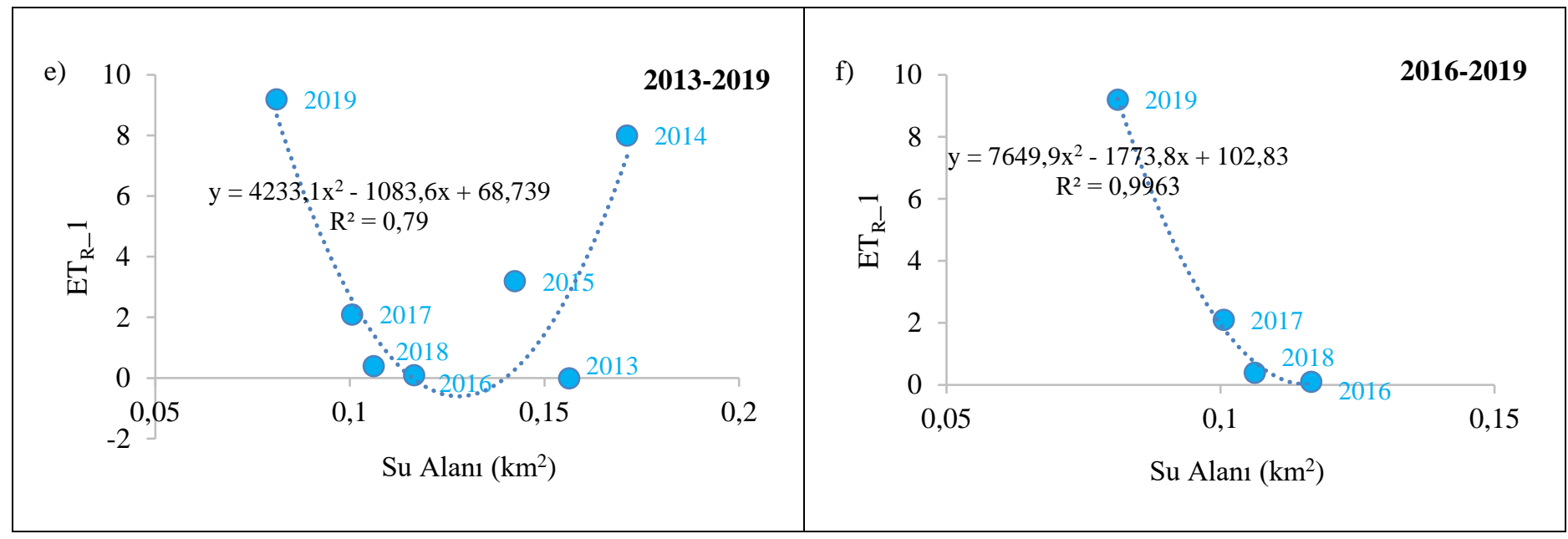

Şekil 10. Kurak dönemde 2013-2019 yılları arasında NDWI ile belirlenen su alanı ile SPI1 (a) 2016-2019 yılları arasında alan ile SPI1 (b), 2013-2019 yılları arasında alan ile $\mathrm{ET}_{\mathrm{P}} 1$ (c), 2013-2019 yılları arasında $\mathrm{ET}_{\mathrm{R}} 1$ ile SPI1 (d), 2013-2019 yıllar1 arasinda alan ile $\mathrm{ET}_{\mathrm{R}} 1$ (e) ve 2016-2019 yılları arasındaki alan ile $\mathrm{ET}_{\mathrm{R}} 1$ (f) ilişkisi

Yağışlı ve kurak dönemlerin uzun yıllar seyrinde potansiyel buharlaşmanın yüksek olduğu dönemler aynı zamanda kuraklığın da yüksek olduğu dönemlerdir. Kurak dönemde potansiyel buharlaşmanın yüksek olduğu dönemde yağışlar

belirgin bir şekilde düşükken $\left(\mathrm{R}^{2}=0,1643\right)$ (Şekil 11b), yağışı dönemde potansiyel buharlaşma ile yağış ilişkisi görülmez $\left(\mathrm{R}^{2}=0,0799\right)$ (Şekil 11a).

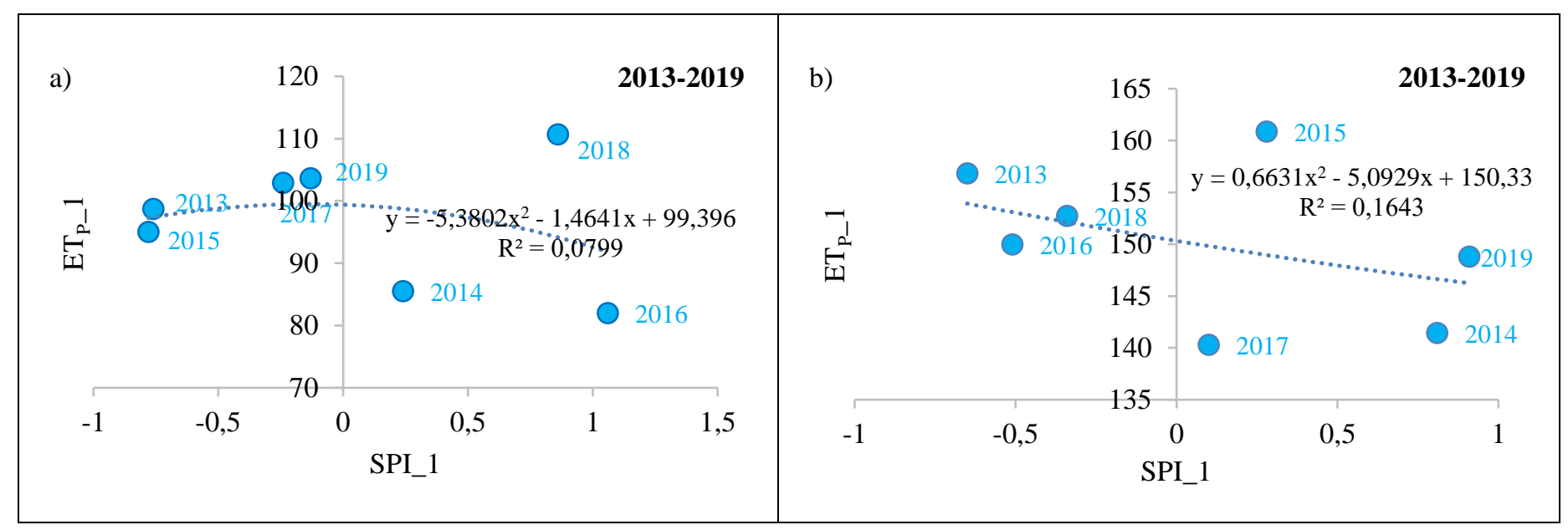

Şekil 11. 2013-2019 yılları arasındaki yağışlı dönem (a), kurak dönem (b) ETP1-SPI1 ilişkisi

Yağışlı dönemde potansiyel buharlaşmanın su kaplı alanlardaki değişime doğrudan etkisi uzun yıllar birlikte değerlendirildiğinde düşüktür $\left(\mathrm{R}^{2}=0,2858\right)$ (Şekil 12a, b). 20162019 Yağışlı döneminde potansiyel buharlaşmadan daha ziyade, yağışlar su kaplı alanın değişiminde etkindir $\left(\mathrm{R}^{2}=0,9217\right)$ (Şekil 12d). Yağmurun dişında farklı bileşenlerin de (eriyen kar suyu, yüzey akışı veya yeraltı suyu beslenimi) su kaplı alanların değişiminde etkilidir. 2013-2019 yılları arasındaki yağışlı dönemde birikmiş suyun aylık değişiminin su alanlarına etkisi düşük iken $\left(\mathrm{R}^{2}=0.3739\right)$ (Şekil 12e), 2016-2019 yağışlı döneminde birikmiş suyun aylık değişimine bakıldığında ise, bu bileşenlerin su kaplı alanların değişimindeki etkin rolü görülmektedir $\left(\mathrm{R}^{2}=0,8482\right)$ (Şekil 12f). 


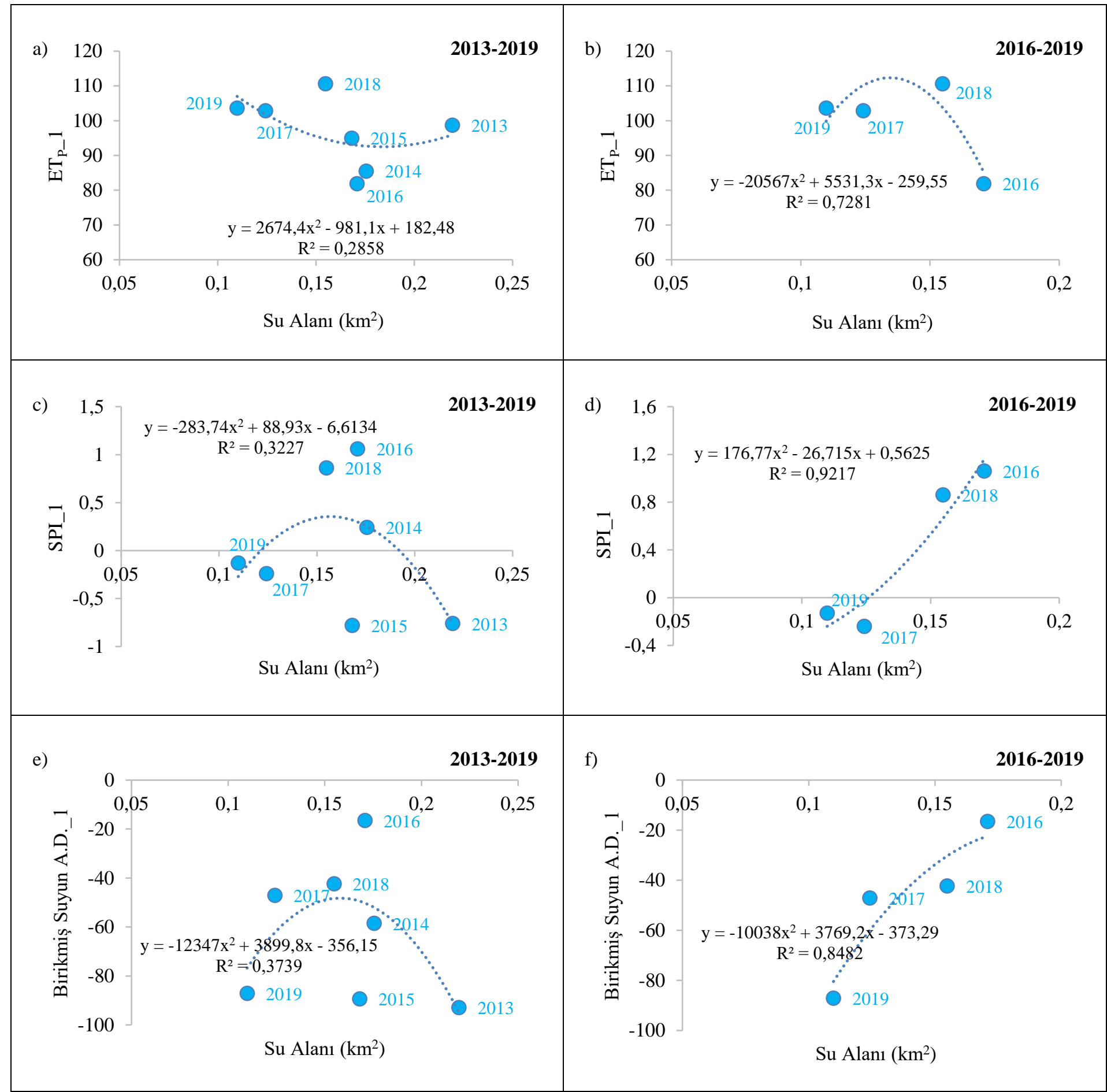

Şekil 12. Yağışlı dönemde 2013-2019 yılları arasında NDWI ile belirlenen su alanı ile ETP1 (a), 2016-2019 yılları arasındaki su alanı-ETP1 (b), 2013-2019 yılları arasındaki SPI1 ile su alanı (c), 2016-2019 yılları arasındaki SPI1-su alanı (d), 2013-2019 yıllar1 arasındaki Birikmiş Suyun Aylık Değişimi-1 ile su alanı (e), 2016-2019 yılları arasında Birikmiş Suyun Aylık Değişimi-1 ile su alanı (f) arasındaki ilişki

Uzun yıllar yağışlı dönemdeki potansiyel ve gerçek buharlaşma, son iki yllın haricinde (2017 ve 2018) gerçek buharlaşma potansiyel buharlaşmaya eş değerdedir $\left(\mathrm{R}^{2}=1\right)$ (Şekil13b). Ancak uzun dönemde 2017-2018 yılları hesaba katıldığında gerçek ve potansiyel buharlaşma arasında anlamlı bir iliş̧ki görülmemektedir (Şekil 13a). 2018 yllında ETP'nin $E T_{R}$ 'den daha yüksek olması beklenenden daha fazla yağış ile açılanabilir. Bu anomali Şekil 13a'daki $\mathrm{ET}_{\mathrm{R}}$ ile $\mathrm{ET}_{\mathrm{P}}$ arasındaki ilişkiyi zayıf hale getirebilmektedir. Kurak dönemde ise potansiyel buharlaşmanın maksimum olduğu dönemlerde gerçek buharlaşma minimumdur. Kurak dönemde potansiyel buharlaşma arttıkça su noksanı $\operatorname{artar}\left(\mathrm{R}^{2}=0,8677\right)$ (Şekil 13c). Yağışlı dönemde su bütçesindeki aktif değişim, su kaplı alandaki değişimi doğrudan etkiler. Kurak dönem için böyle bir durum söz konusu değildir. 


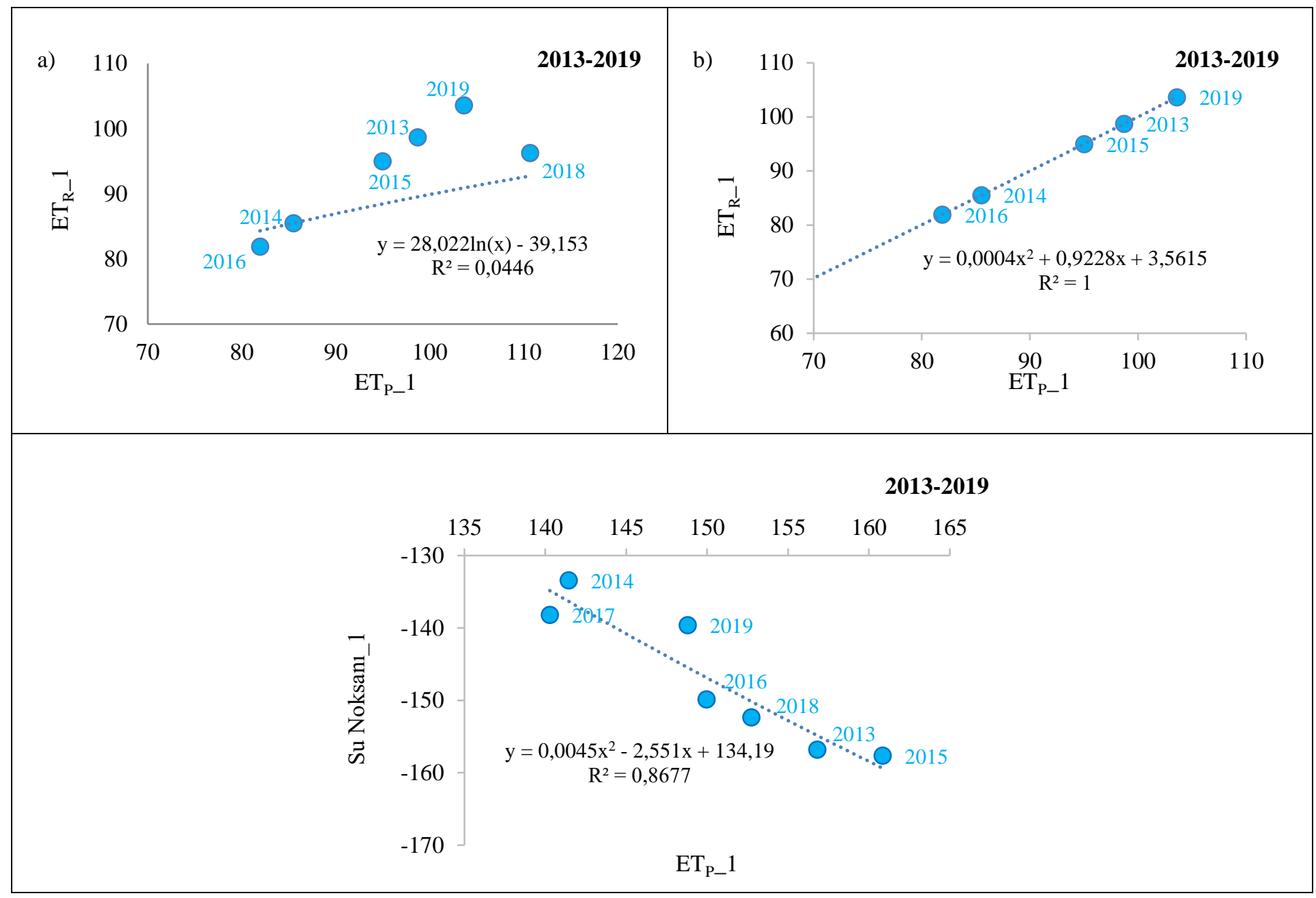

Şekil 13.Yağışlı dönem 2013-2019 yılları arasındaki $\mathrm{ET}_{\mathrm{P}} 1-\mathrm{ET}_{\mathrm{R}} 1$ (a), 2013-2019 yılları arasındaki (2017-2018 hariç) $\mathrm{ET}_{\mathrm{P}} 1-\mathrm{ET}_{\mathrm{R}} 1$ (b) ve 2013-2019 yılları arasındaki Su Noksanı1-ETP1 (c) ilişkisi

1 aylık dönem incelemesinde 2013-2019 yılları arasında yă̆ışlı dönem sonu olan Mayıs ve kurak dönem sonu olan Ağustos aylarının SPI-alan ve ET $\mathrm{P}_{\mathrm{P}}$-alan arasındaki ilişki her iki dönem için ayrı ayrı dağılım grafikleri ile gösterilmiştir (bkz. Şekil 10a, b, c), Şekil 12a, b, c, d).1 aylık dönem incelemesine göre Mayıs ayları içerisinde en kurak yıl; -0,78 (hafif kuraklık) SPI değeri ile 2015 ve $-0,76$ (hafif kuraklı) değeri ile 2013 yıllarıdır. Ağustos ayı içerisinde ise 2013 yılı $-0,65$ SPI değeriyle hafif kurak iken, 2014 ylli orta nemli, 2015 y1lında ise normal civarında gerçekleşmiştir. 2016 yılında hafif kuraklık etkili iken, 2017-2018 yılları normal civarında ve 2019 yılında ise orta derecede nemlilik etkili olmuştur.

1 aylık dönem incelemesinde su alanlarının değişiminde yağışlı dönem sonu, uzun yıllar seyrinde SPI ve ET etkisi düşük iken, 2016-2019 yıllarında bu etki daha yüksektir. Ayrıca Mayıs ayında su alanlarında meydana gelen değişimde yağışlar ve su bütçesinde meydana gelen değişim su alanlarını daha fazla etkilemekte, buharlaşmanın yağışlardan düşük olması ET etkisinin düşük olmasına sebep olmaktadır. Ağustos ayına bakıldığında Mayıs ayında görülen bu durumun aksine buharlaşmanın yă̆ışlardan daha baskın olması ET değerlerinin alanların değiş̧iminde daha etkili olduğunu gösterir. Yağışlı dönemde sulak alanların SPI, kurak dönemde ise $\mathrm{ET}_{\mathrm{P}}$ ile kuvvetli ilişki vermesi beklenmesine rağmen, SPI'nın negatif ve anlamsız ilişkiler görülmesi sebebinin, sulak alanın karma yapısı (Şekil 2a), bitki örtüsü ile kaplı olması ve dikey yönlü meydana e-ISSN: 2148-2683 gelen değişimlerin olabileceği düşünülmektedir. SPI, ET ve alan arasındaki ilişkinin beklenenden düşük olması, SPI ve ET ile ilişkilendirilmesinin 1 aylık dönemsel inceleme ile yetersiz kaldığını göstermektedir.

\subsubsection{Ayllk Dönem Íncelemesi}

3 aylık dönem incelemesinde 2013-2019 yılları arasında ilkbahar (Mart, Nisan, Mayıs) ve yaz mevsimleri (Haziran, Temmuz, Ağustos) SPI ile alan ve ET $\mathrm{P}_{\mathrm{P}}$ ile alan arasındaki ilişki her iki dönem için ayrı dağılım grafikleri ile gösterilmiștir (Şekil 14a, b, c, d, e, f, Şekil 15a, b, c, d).

İlkbahar dönemlerinde SPI ve $\mathrm{ET}_{\mathrm{P}}$ ile yağışlı dönem sonundaki su kütlesi alanı arasında sırasıyla, $R=0,40$ ve $R=-0,14$ çok zayıf korelasyonlar görülmektedir. Yaz dönemi ve kurak dönem sonundaki su kütlesi alanı arasında sırasıyla $R=-0,03$ çok zayıf ve $\mathrm{R}=-0,73$ ile kuvvetli düzeyde ilişki saptanmıştır. İlkbahar döneminde SPI ile alan arasında orta düzeyde pozitif, yaz dönemlerinde negatif çok zayıf korelasyon görülürken, $\mathrm{ET}_{\mathrm{P}}$ ile alan arasında negatif ilişki olmakla birlikte, buharlaşmanın daha baskın olduğu Ağustos ayında bu ilişki çok daha yüksektir.

Yağışlı ve kurak dönem sonlarında su kütlelerindeki alansal değişimde yaz dönemindeki kuraklığın etkisi büyüktür. $\mathrm{Bu}$ değişimde SPI'ya $(\mathrm{R}=-0,03)$ kıyasla $\mathrm{ET}_{\mathrm{P}}$ 'nin $(\mathrm{R}=-0,73)$ etkisi çok daha fazladır. Yaz döneminde yağışların azalırken buharlaşmanın artması, artan buharlaşma sonucu su kütlesinin alanında azalma meydana geldiğini göstermektedir. 
İlkbahar dönemlerinde, SPI ile su kaplı alan arasında uzun dönemde polinomsal pozitif bir ilişki olup, kuvvetli bir ilişki görülmemektedir $\left(\mathrm{R}^{2}=0,1849\right)$ (Şekil14a). 2014-2018 döneminde ise yağış ve su kaplı alan arasındaki pozitif ilişki $\left(\mathrm{R}^{2}=0,9571\right)$ (Şekil 14b) yüksektir. Yağışlı dönemin 3 aylık halinde birlikte incelenmesinde, 2013-2019 y1llarında potansiyel $\left(\mathrm{R}^{2}=0,0244\right)$
(Şekil 14c) ve gerçek buharlaşmanın $\left(\mathrm{R}^{2}=0,0806\right)$ (Şekil 14d) su alanları üzerinde doğrudan etkisi oldukça düşüktür. $\mathrm{Su}$ bütçesinde meydana gelen değişimler su kaplı alanları etkilemekte, belirli dönemlerde zemin rezervinin kullanımı su alanlarını azaltmaktadır $\left(\mathrm{R}^{2}=0,8293\right)$ (Şekil 14f, e).

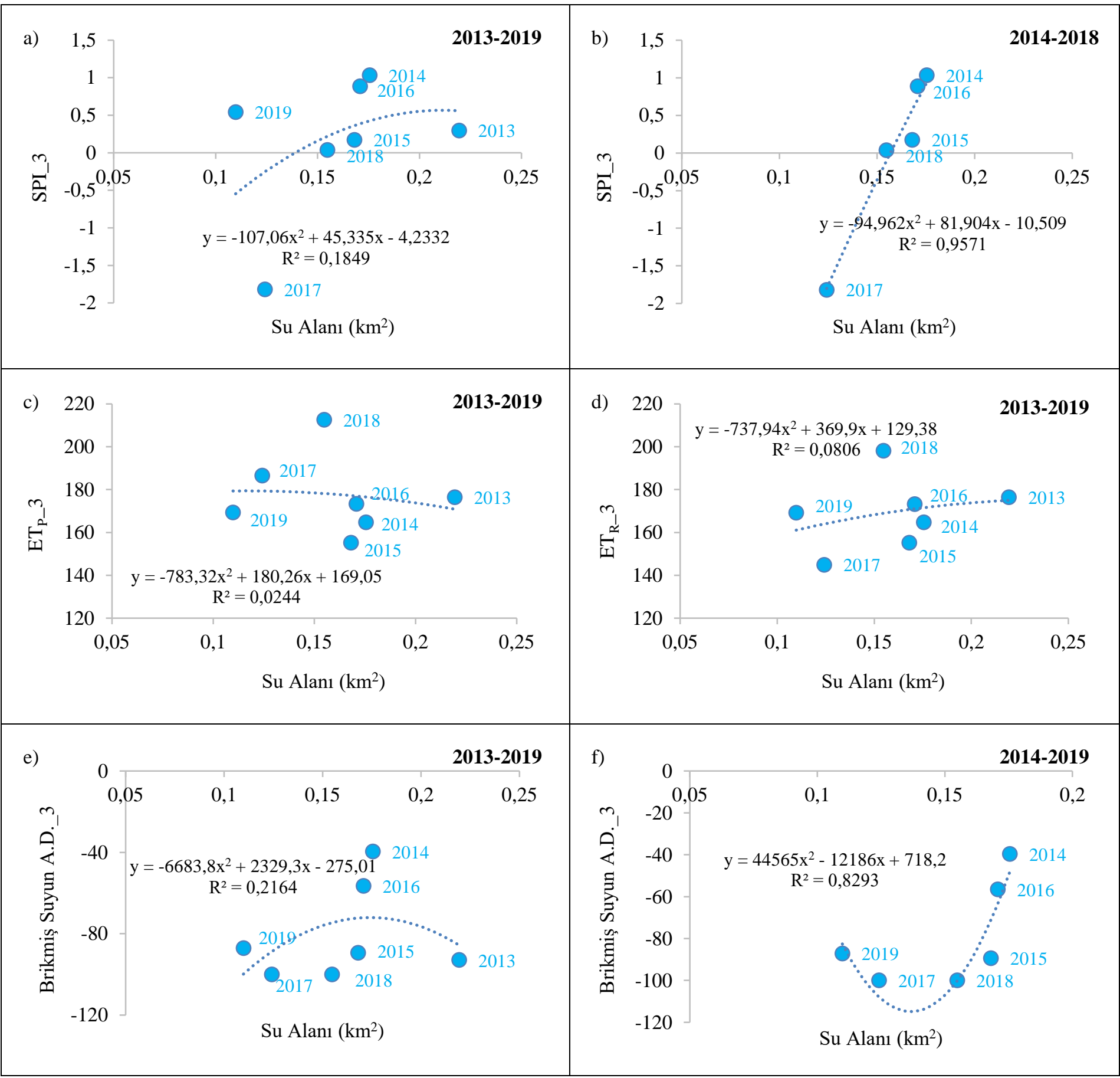

Şekil 14. Yağışlı dönem 2013-2019 yılları arasında NDWI ile belirlenen su alanı ile SPI3 (a), 2014-2018 yılları arasında su alanı ile SPI3 (b), 2013-2019 yılları arasında su alanı ile $\mathrm{ET}_{\mathrm{P}} 3$ (c), 2013-2019 yılları arasında su alanı ile $\mathrm{ET}_{\mathrm{R}} 3$ (d), 2013-2019 yılları arasında su alanı ile Birikmiş Suyun Aylık Değişimi-3 (e), 2014-2019 yılları arasında su alanı ile Birikmiş Suyun Aylık Değişimi-3 (f) arasındaki iliş̧ki

Kurak dönemde su kaplı alanların değişiminde ise SPI doğrudan ilişkilidir $\left(\mathrm{R}^{2}=0,5038\right)$ (Şekil 15a). 2016-2019 yılları arasında bu ilişki $\left(\mathrm{R}^{2}=-0,834\right)$ 'dir (Şekil $\left.15 \mathrm{~b}\right)$. $E T_{\mathrm{P}}$, HaziranAğustos dönemindeki uzun dönem anomalisinde su kaplı alanlar e-ISSN: $2148-2683$ üzerinde etkilidir $\left(\mathrm{R}^{2}=0,8284\right)$. Delta üzerinde artan potansiyel buharlaşma, su kaplı alanların azalmasına gerçek buharlaşma $\left(\mathrm{ET}_{\mathrm{R}}\right)$ ise yağışlarla da ilişkili olduğundan su kaplı alanların artmasına neden olur. 2014 ve 2019 yılları gözardı edildiğinde 
potansiyel buharlaşmanın artmasının su alanlarının azalmasına etkisindeki korelasyon katsayıs1 $\mathrm{R}^{2}=-0,9623$ (Şekil 15c) iken gerçek buharlaşmanın alanların artmasına etkisindeki korelasyon katsayıs1 $\mathrm{R}^{2}=0,9934$ 'tür (Şekil 15d).

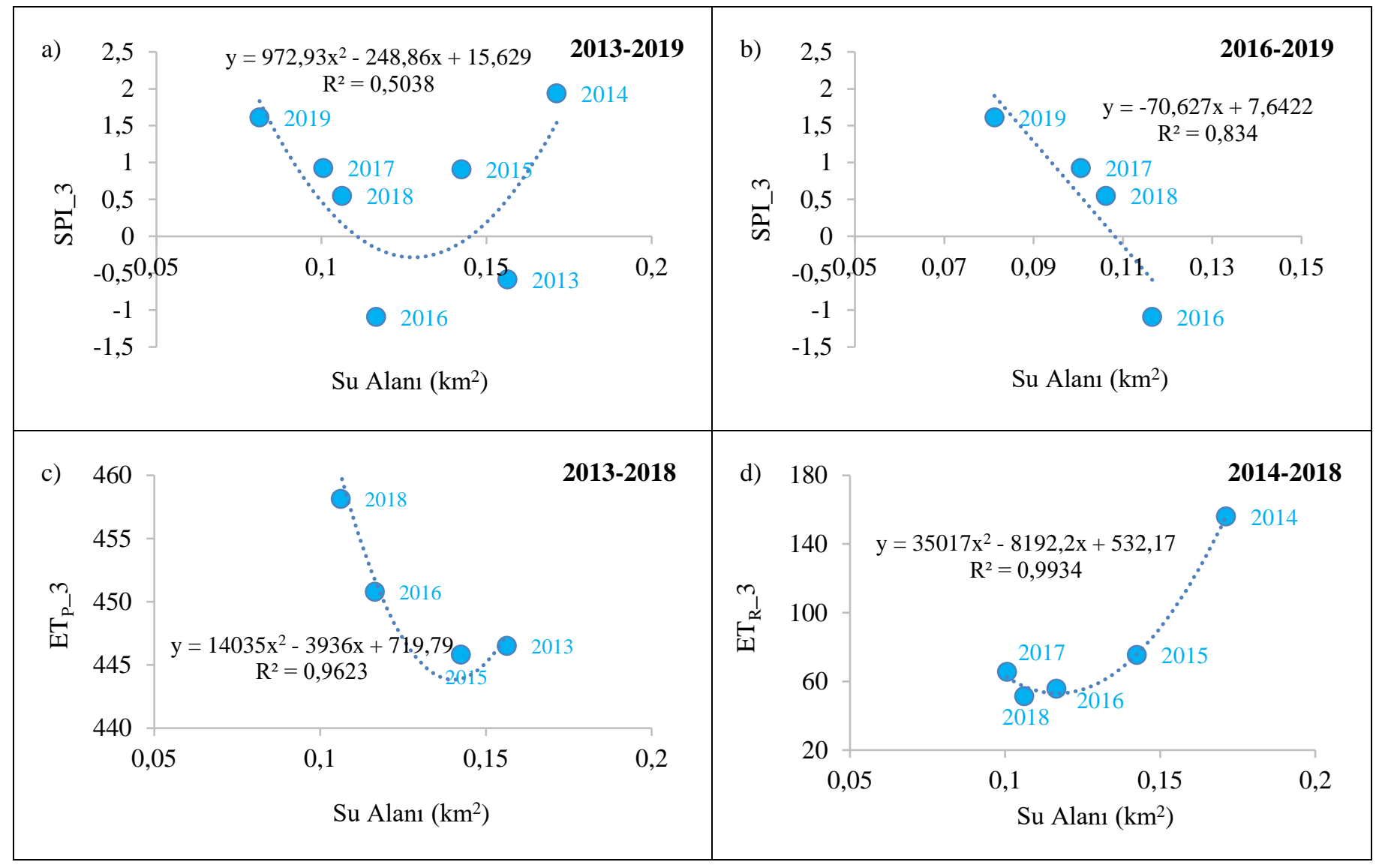

Şekil 15. Kurak dönemde 2013-2019 yılları arasında NDWI ile belirlenen su alanı ile SPI3 (a), 2016-2019 yılları arasında alan ile SPI3 (b), 2013-2018 yılları arasında alan-ET 3 (c) ve 2014-2018 yılları arasında alan ile $\mathrm{ET}_{\mathrm{R}} 3$ (d) arasındaki ilişki

Genel olarak mevsimsel ve aylık değerlendirmeler deltada yer alan sulak alanlar üzerinde ET'nin yăğşlardan daha etkili olduğunu göstermektedir. 1 aylık değerlendirmede, kısa bir süre içinde meydana gelen değişimler su alanlarındaki değişimi açıklamada mevsimsel etki kadar açıklayıcı olmamaktadır. ET ve SPI etkisine ek olarak çalışma sahasının yeraltı suyu beslenimi ve yüzey akışı ile su bütçesinde meydana gelen değişimlerin de bu alanlar üzerinde büyük bir rolü olduğunu göstermektedir.

$\mathrm{Bu}$ çalışmadaki su kütlelerinin alansal değişiminde $\mathrm{ET}_{\mathrm{P}}$, SPI' den daha etkili olduğu söylenebilir. Ayrıca kış ve ilkbahar aylarında yağışların bir kısmı sızma olayı ile kaybedilmekte, yaz aylarında meydana gelen buharlaşma, rüzgar ile şiddetlendiğinde su alanlarında önemli ölçüde küçülmeye sebep olmaktadır.

\section{Sonuçlar}

Dünyanın pek çok ülkesinde olduğu gibi ülkemizin de en büyük sorunlarından birisi olan kuraklık, canlı yaşamı, ekolojik ve sosyo-ekonomik sistemler üzerinde doğrudan ve dolaylı olarak tehdit oluşturmaktadır. Meteorolojik, hidrolojik, tarımsal ve sosyo-ekonomik kuraklık olarak dört ayrı grupta incelenen bu doğal afeti belirlemek, nitelendirmek ve izlemek amaciyla birçok kuraklık analiz ve yöntemleri kullanılmaktadır. Bu amaçlar doğrultusunda Uzaktan Algılama, özellikle su kütlelerinde meydana gelen değişimlerin izlenmesinde ve hidrolojik kuraklığın yorumlanmasında pozitif sonuçlar elde edilmesine katkı sağlayan önemli bir araçtır.

$\mathrm{Bu}$ çalışmada Çanakkale Umurbey Deltası'ndaki sulak alanların yağışlı ve kurak dönemler sonundaki alansal ve zamansal değişimi belirlenmiş ve alansal değişim ile meteorolojik ve hidrolojik kuraklık verileri arasındaki ilişki incelenmiştir. Landsat 8 uydu görüntülerine uygulanan MNDWI kullanarak elde edilen, yağışlı ve kurak olmak üzere toplam 14 döneme ait su ile kaplı alan verisi ile aynı dönemlere ait SPI ve Thornthwaite verileri arasındaki ilişki korelasyon-regresyon analizi ile incelenmiştir. Çalışmanın bulguları doğrultusunda ulaşılan sonuçlar aşağıdaki şekildedir;

- Evapotranspirasyon ile su kaybının belirlenmesinde Thornthwaite, meteorolojik kuraklığın yıllık değişiminde ise SPI daha anlamlı sonuçlar vermektedir.

- MNDWI kullanarak elde edilen su ile kaplı alan verisi ile aynı dönemlere ait SPI ve Thornthwaite verileri arasında tutarlı korelasyonlar elde edilmiştir. Su alanlarının aylık ve mevsimlik değişimlerinin 1 aylık dönem incelemesinde, uzun yıllar seyrinin yağışı dönem sonunda, SPI ve ET etkisinin düşük olduğu görülmüştür. Ağustos ayına bakıldığında buharlaşmanın yağışlardan daha baskın olması ET değerlerinin su 
alanlarının değişiminde daha etkili olduğunu göstermektedir. 3 aylık dönem incelemesinde yağışlı ve kurak dönem sonlarında su kütlelerindeki alansal değişimde yaz dönemindeki kuraklığın etkisinin büyük olduğu görülmüştür.

- Yapilan analizler sonucunda, su ile kaplı alanların 2013 yılından 2019 yılına kadar olan süreçte azalma eğiliminde olduğu görülmüştür.

- Yağışların fazla olmasına karşın, buharlaşmanın da yüksek olması, sulak alanın yaz mevsiminde yaşanan doğal kurak süreçten çok fazla etkilenmediğini, bunda yeraltı ve yer üstü kaynaklı beslenimin etkili olabileceği ve değişimin yatay yönden ziyade dikey yönde meydana geldiği söylenebilir.

- 2016-2019 döneminde yağış ve buharlaşmanın sulak alanlar üzerindeki etkisi uzun döneme kiyasla daha yüksek korelasyon göstermiştir. Bunda en büyük etken meteorolojik verilerdeki anomalilerdir.

- Uzaktan algılama, su kütlelerinde meydana gelen değişimlerin izlenmesinde ve bu değişimin modellenmesinde önemli katkı sağlar. Sulak alan ve olmayan alanların ayrımı 15 m mekânsal çözünürlüklü Landsat veri seti ile k1smen belirlenebilmektedir ancak arazinin su ile bitki karma yapısı nedeniyle, bazı alanlarda çok net ayrım sağlanamamıştır. Bu nedenle ayrımın daha kolay ve doğru yapılabilmesi ve ortalama bir standartda incelenebilmesi için eşik değerler seçilmiştir.

- Uzaktan algılamadan üretilen veriler, meteorolojik veriler ile kolaylıkla ilişkilendirilebilir. Yapılan çalışmada elde edilen sonuçlar neticesinde sulak alanlarda meydana gelen meteorolojik ve hidrolojik kuraklığın belirlenmesinde MNDWI'nin katk1 sağladığı görülmüştür.

Çalışma kapsamında elde edilen sonuçlar su kaynaklarının devamlılı̆̆ı açısından kuraklığın ne denli önemli olduğunu göstermektedir. Bununla birlikte, sulak alanlardaki değişiminde sadece hidrometeorolojik parametrelerin değil, su tüketimi (içme suyu, tarımsal sulama, sanayi faaliyleri için kullanım vb.) parametrelerinin de değerlendirilmesi gerektiği sonucuna ulaşılmıştır. Çalışmanın sonuçları uzaktan algılama yöntemlerinin sulak alanların yönteriminde ne denli başarılı ve etkili bir yöntem olduğunu bir kere daha ortaya koymaktadır.

\section{Teşekkür}

Yazarlar uydu görüntülerinin paylaşımından dolayı Amerika Birleşik Devletleri Jeoloji Araştırmaları Kurumu'na (USGS), meteorolojik verilerin paylaşımından dolayı T.C. Orman ve Su İşleri Bakanlığı Meteoroloji Genel Müdürlüğü’ne teşekkür eder.

\section{Kaynakça}

1. Karabulut, M. (2015). Farklı Uzaktan Algılama Teknikleri Kullanılarak Göksu Deltası Göllerinde Zamansal Değişimlerin İncelenmesi. Journal Of International Social Research, 8(37).

2. Çağırankaya, S., e Köylüoğlu, F., (2013). Sulak Alan Kavramı, Sulak Alan Nedir? Sulak Alan Sinıflandirması. Meriç, B.T.,e Çağırankaya, S., (ed.) Sulak Alanlar. (s. 7-38) içinde. http://www.turkiyesulakalanlari.com/wpcontent/uploads/sulak-alanlar-kitabı-baskı-onayı-için.pdf
3. Keçer, M., Duman, T. (2007). Yapay Etkinliklerin Göksu Deltası Gelişimine Etkisi Mersin-Türkiye”, MTA Dergisi, s. 134, s. 17-26.

4. Korkanç, S. Y. (2004). Sulak Alanların Havza Sistemi İçindeki Yeri. Journal of Bartin Faculty of Forestry, 6(6), 117-126.

5. Polat, Z., Deniz, B., Kılıçaslan, Ç., Kara, B. (2011) “Aydın İlindeki Sulak Alanlara Rekreasyonel Açıdan Bir Bakış”, II. Türkiye Sulak Alanlar Kongresi, 22-24 Haziran 2011, Kırşehir / Türkiye, 149-155.

6. Karaman M., Budakoglu M., Avci Z.D.U., Ozelkan E., Bulbul A., Civas M., Tasdelen S., (2015). Determination of Seasonal Changes in Wetlands Using Chris/Proba Hyperspectral Satellite İmages: A Case Study From Acigöl (Denizli), Turkey, Journal of Environmental Biology, 36(1), 73-83.

7. Harou, P. (1995). Wetlands Economics and Land Use. In: Environmental and Land Use Issues, Crheam-Eaae. 540 P.

8. Marsh, W. (1991). Wetlands, Habitat and Land Use Planning, Environmental Applications, 2nd Editions, John Wiley and Sons Inc. New York, Usa.

9. TMMOB Orman Mühendisleri Odası, (2007). Sulak Alanların ve Sazlık Alanların Tahribi ve Yok Edilmesi Kuraklık ve Doğa Felaketine Yol Açmıştır”, yıl: 44 sayı: 7-8-9 TemmuzAğustos-Eylül 2007. Erişim adresi https://ormuh.org.tr/uploads/docs/magazines/DERGI 2007 $\underline{\text { 3.pdf }}$

10. Aydın vd. (2013). Sulak Alan Hidrolojisi. Meriç, B.T., Ve Çağırankaya, S., (Ed.) Sulak Alanlar. (S. 41-66) içinde. url:http://www.turkiyesulakalanlari.com/wpcontent/uploads/sulak-alanlar-kitabı-bask1-onay1-için.pdf

11. Karaman, M., Özelkan, E., Taşdelen, S. (2018). Dar Nehirlerin Sentinel2-A Uydu Görüntüleri ile Belirlenebilirliğinde Havza Hidrojeolojisinin Etkisi: Karamenderes (Çanakkale) Örneği, Doğ Afet Çev Derg, 2018; 4(2): 140-155.

12. Pastor, Melendez I., Pedreno, Navarro. J., Gomez, Ignacio, Koch, Magaly (2010). Detecting Drought Induced Environmental Changes in A Mediterranean Wetland by Remote Sensing", Applied Geography, s. 3 (2), s. 254-262.

13. Cebe, M., Kardaş, F. (2018). Doğa Koruma ve Çevre Eğitimi Açısından Sulak Alanların İşlevleri. Menba Kastamonu Üniversitesi Su Ürünleri Fakültesi Dergisi, 4(1), 29-35.

14. Yıldız, N., Ve Yılmaz, S. (2009). Sulak Alanların Önemi ve Gavur Gölü. Kahramanmaraş Sempozyumu, Kahramanmaraş.

15. Hızlı vd. (2013). Sulak Alan Mevzuatı. Meriç, B.T., Çağırankaya, S., (ed.) Sulak Alanlar. (s. 81-96) içinde. url:http://www.turkiyesulakalanlari.com/wpcontent/uploads/sulak-alanlar-kitab1-baskı-onayı-için.pdf

16. İnaç, S. (2001). Kahramanmaraş Türkoğlu Gavur Gölü Sulak Alanında Yaban Hayatı, Türkiye Ormancılar Derneği, I. Ulusal Ormanc1lık Kongresi Bildiri Kitab1, 19-20 Mart 2001, Ankara, S: 536-543.

17. Reis, S., H. M. Yılmaz. "Seyfe Gölünün Zamansal Değişiminin Uzaktan Algılama Tekniği ile İzlenmesi, Türkiye Ulusal Fotogrametri ve Uzaktan Algılama Birliği IV." (2007): 5-7.

18. Anlı, A. S., Polat, H. E., Semiz, G. D. (2011). Kırşehir İlinin Kuraklığının Analizi Ve Sulak Alanlara Etkisi. II. Türkiye Sulak Alanlar Kongresi. Bildiriler, 22-24.

19. Özelkan, E. (2019). Uzaktan Algılama ile Belirlenen Baraj Gölü Alanının Zamansal Değişiminin Meteorolojik Kuraklık 
ile Değerlendirilmesi: Atikhisar Barajı (Çanakkale) Örneği. Türk Tarım ve Doğa Bilimleri Dergisi, 6(4), 904916.

20. Ozelkan, E., Chen, G., Ustundag, B.B. (2016). Multiscale Object-Based Drought Monitoring and Comparison in Rainfed and Irrigated Agriculture From Landsat 8 Oli Imagery", International Journal of Applied Earth Observation and Geoinformation, 44, 159-170.

21. Mishra, A.K., Singh, V.P. (2010). A Review of Drought Concepts. Journal of Hydrology, 391 (1-2): 204-216.

22. Özelkan, E., Karaman, M. (2018). Baraj Göllerindeki Meteorolojik ve Hidrolojik Kuraklığın Etkisinin Çok Zamanlı Uydu Görüntüleri ile Analizi: Atikhisar Barajı (Çanakkale) Örneği”, Ömer Halisdemir Üniversitesi Mühendislik Bilimleri Dergisi, 7(2), 1023-1037.

23. MGM (Meteoroloji Genel Müdürlüğü) (2018). https://www.mgm.gov.tr/veridegerlendirme/kuraklikanalizi.aspx? $\mathrm{d}=$ yontemsinif. Erişim Tarihi: (2.11.2018).

24. Arslan, O., Bilgil, A., Veske, O. (2016). Standart Yağiş İndisi Yöntemi İle Kızılırmak Havzası'nın Meteorolojik Kuraklık Analizi. Ömer Halisdemir Üniversitesi Mühendislik Bilimleri Dergisi, 5(2), 188-194.

25. Lu N., Chen S., Wilske B., Sun G., Chen J. (2011). Evapotranspiration and Soil Water Relationships in A Range of Disturbed and Undisturbed Ecosystems in The Semi-Arid Inner Mongolia, China, Journal of Plant Ecology, 4(1-2), 4960.

26. Liu W., Wang L., Zhou J., Li Y., Sun F., Fu G., Li X., Sang Y.-F. (2016). A Worldwide Evaluation of Basin-Scale Evapotranspiration Estimates Against The Water Balance Method, Journal of Hydrology, 538, 82-95.

27. Karaman M., Uça Avcı Z. D., Budakoğlu M., Taşdelen S., Özelkan E., Papila İ. (2011). Flamingoların Beslenim Alanlarındaki Tahribatın Uzaktan Algılama Yöntemleri ile Değerlendirilmesi: Acıgöl (Denizli) Örneği: II, II. Türkiye Sulak Alanlar Kongresi, 22-24 Haziran, Kırşehir.

28. Demir, Y., Doğan Demir, A., Meral, R., Alaaddin, Y. (2015). Bingöl Ovası İklim Tipinin Thornthwaite ve Erinç İndisine Göre Belirlenmesi.Türk Tarım Ve Doğa Bilimleri Dergisi 2(4): 332-337.

29. Günal, N., Özdemir, Y. (2010). Çok Zamanlı Landsat Uydu Görüntüleri Kullanılarak Neyriz Göllerinin (İran) Yüzey Değişiminin Belirlenmesi. III. Uzaktan Algılama ve Coğrafi Bilgi Sistemleri Sempozyumu, 11 - 13 Ekim 2010, Gebze Kocaeli.

30. Şener, E., Davraz, A., İsmailov, T. (2005). Burdur Gölü Seviye Değişimlerinin Çok Zamanlı Uydu Görüntüleri ile İzlenmesi. Türkiye Kuvaterner Sempozyumu Turqua-V, İTÜ Avrasya Yer Bilimleri Enstitüsü, 148-156.

31. Özelkan, E. (2020). Water Body Detection Analysis Using NDWI Indices Derived from Landsat-8 OLI. Polish Journal of Environmental Studies, 29(2), 1759-1769.

32. Özelkan, E. (2019a). Comparison of Remote Sensing Classification Techniques for Water Body Detection: A Case Study in Atikhisar Dam Lake (Çanakkale). Cumhuriyet Science Journal, 40(3), 650-661.

33. Sunar, F. (1998). An Analysis Of Changes in A Multi-Date Data Set: A Case Study in The İkitelli Area, İstanbul, Turkey, Int. J. Remote Sensing, 19:2, Pp. 225-235.

34. Koç, A., Çoban, H., Yener, H. (2006). Değişim Belirlemede Görüntü Fark1 Yönteminin Uygulanması. İstanbul Üniversitesi Orman Fakültesi Dergisi, 56(2), 77-92.
35. Karaman, M., Budakoğlu, M., Avci, Z. D. U., Özelkan, E., Taşdelen, S., Bülbül, A., Civaş, M. (2013). Chris/Proba Hiperspektral Uydu Görüntüleri ile Sulak Alanlarin Mevsimsel Değişiminin İncelenmesi: Acigöl (Denizli), Türkiye.

36. Mcfeeters, S. K. (1996). The Use of The Normalized Difference Water Index (NDWI) in The Delineation of Open Water Features" International Journal of Remote Sensing, $17(7), 1425-1432$.

37. Xu, H. (2006). Modification of Normalised Difference Water Index (NDWI) to Enhance Open Water Features in Remotely Sensed İmagery" International Journal Of Remote Sensing, 27(14), 3025-3033.

38. Ji L., Zhang L., Wylie B. (2009). Analysis of Dynamic Thresholds for The Normalized Difference Water Index. Photogrammetric Engineering \& Remote Sensing, 75 (11), 1307-1317.

39. Akar, İ., Maktav, D., Günal, N. (2012). Göl Yüzeyi Değişimlerinin Belirlenmesinde Farklı Dijital Görüntü İşleme Tekniklerinin Kullanılması. Journal of Aeronautics \& Space Technologies/Havacilik ve Uzay Teknolojileri Dergisi, 5(4).

40. Schultz, G.A., Engman, E.T. (2012). Remote Sensing in Hydrology and Water Management, Springer Science \& Business Media.

41. T.C. Çanakkale Valiliği Çevre ve Şehircilik İl Müdürlüğü, Çanakkale İli 2016 Y1lı İl Çevre Durum Raporu, Hazırlayan Çed ve Çevre İzinlerinden Sorumlu Şube Müdürlüğü, Çanakkale-2017.

42. Doğaner, S. (1994) Çanakkale Boğazı Kıyırının Coğrafyası, Türk Coğrafya Dergisi, (29), 125-159, İstanbul.

43. Erturaç, M. K. (2002). Marmara Denizi Kıyıları Veri Tabanı, Yüksek Lisans Tezi, İTÜ - Avrasya Yerbilimleri Enstitüsü, İstanbul.

44. USGS (United States Geological Survey). (2019). "Earth Explorer." Accessed 20 January 2019. https://earthexplorer.usgs.gov/.

45. Sun, W., Chen, B., Messinger, D., (2014) "Nearest-Neighbor Diffusion-Based Pan-Sharpening Algorithm for Spectral Images", Optical Engineering, 53(1), 013107.

46. Karaman M., (2017). Hipersalin Acıgöl'ün (Denizli) Hidrojeokimyasal Özellikleri ve Uzaktan Algılama Yöntemleri ile Değerlendirilmesi, Doktora Tezi, Pamukkale Üniversitesi, Denizli.

47. Mckee, T. B., Doesken, N. J., Kleist, J. (1993). The Relationship of Drought Frequency and Duration to Time Scales. in Proceedings of The 8th Conference on Applied Climatology (Vol. 17, No. 22, Pp. 179-183). Boston, Ma: American Meteorological Society.

48. Pamuk, G., Özgürel, M., Topçuoğlu, K. (2004). Standart Yağış İndisi (SPI) ile Ege Bölgesinde Kuraklık Analizi. Ege Üniversitesi Ziraat Fakültesi Dergisi, 41(1).

49. Yılmaz, M. (2017). Konya Kapalı Havzası'nın Tmpa Uydu Kaynaklı Yağış Verileri ile Kuraklık Analizi. Journal of the Faculty of Engineering and Architecture of Gazi University, 32(2), 541-549.

50. Ilgar, R. (2010). Çanakkale'de Kuraklık Durumu ve Eğilimlerinin Standartlaştırılmış Yağış İndisi ile Belirlenmesi" Marmara Coğrafya Dergisi, (22), 183-204.

51. Mckee, T.B., Doesken, N.J., Kleist, J. (1995). Drought Monitoring with Multiple Time Scales, January 15-20, American Meteorological Society, Proceeding of The $9^{\text {th }}$ Conference on Applied Climatology, Boston, Pp.233-236. 
52. Vicente-Serrano, S. Beguería, J.I. López-Moreno. (2010). A Multi-Scalar Drought Index Sensitive to Global Warming: The Standardized Precipitation Evapotranspiration Index SPEI. Journal of Climate 23: 1696, Doi: 10.1175/2009jcli2909.1.

53. Beguería, S., Vicente-Serrano, S. M., Reig, F., \& Latorre, B. (2014). Standardized Precipitation Evapotranspiration Index (SPEI) Revisited: Parameter Fitting, Evapotranspiration Models, Tools, Datasets and Drought Monitoring. International Journal of Climatology, 34(10), 3001-3023.

54. Thornthwaite C.W., (1948). An Approach Toward A Rational Classification of Climate, Geographical Review, 38(1), 5594.

55. Bacanl1, Ü. G., Saf, B. (2005). Kuraklık Belirleme Yöntemlerinin Antalya İli Örneğinde İncelenmesi. Antalya Yöresinin İnşaat Mühendisliği Sorunları Sempozyumu.

56. Ölgen, M.K., Birsoy Y. (1992). Thornthwaite Yöntemi ile Su Bilançosunun ve İklim Tipinin Belirlenmesinde Bilgisayar Kullanımı." Ege Coğrafya Dergisi 6.1.
57. Pereira A.R., Pruitt W.O., (2004). Adaptation of The Thornthwaite Scheme for Estimating Daily Reference Evapotranspiration, Agricultural Water Management, 66(3), 251-257.

58. T.C. Orman ve Su İşleri Bakanlığı Meteoroloji Genel Müdürlüğü, Thornthwaite İklim Sinıflandırmasına Göre Türkiye İklimi, Araştırma Dairesi Başkanlığı Klimatoloji Şube Müdürlüğü, Ocak - 2016.

59. Yılmaz, E., Çiçek, İ. (2016). Thornthwaite Climate Classification of Turkey Türkiye Thornthwaite İklim Sinıflandirmasi. Journal of Human Sciences, 13(3), 39733994.

60. Du Z., Li W., Zhou D., Tian L., Ling F., Wang H., Gui Y., Sun B. (2014). Analysis of Landsat-8 Oli Imagery for Land Surface Water Mapping. Remote Sensing Letters, 5 (7), 672.

61. Feyisa G.L., Meilby H., Fensholt R., Proud S.R. (2014). Automated Water Extraction Index: A New Technique for Surface Water Mapping Using Landsat Imagery. Remote Sensing Of Environment, 140, 23. 